Int. J. Dev. Biol. 53: 813-826 (2009)

doi: $10.1387 / \mathrm{ijdb} .072556 \mathrm{cc}$

\title{
Reptile scale paradigm: Evo-Devo, pattern formation and regeneration
}

\author{
CHENG CHANG ${ }^{1,2}$, PING WU ${ }^{1}$, RUTH E. BAKER ${ }^{3}$, PHILIP K. MAINI ${ }^{3,4}$, LORENZO ALIBARDI $^{*, 5}$ \\ and CHENG-MING CHUONG*,1
}

\begin{abstract}
${ }^{1}$ Department of Pathology, Keck School of Medicine, University of Southern California, Los Angeles, California, USA, ${ }^{2}$ School of Life Science, Lanzhou University, Lanzhou, Gansu, China, ${ }^{3}$ Centre for Mathematical Biology, Mathematical Institute, University of Oxford, ${ }^{4}$ Oxford Centre for Integrative Systems Biology, Department of Biochemistry, University of Oxford, UK and ${ }^{5}$ Dipartimento di Biologia Evoluzionistica Sperimentale, University of Bologna, Bologna, Italy
\end{abstract}

\begin{abstract}
The purpose of this perspective is to highlight the merit of the reptile integument as an experimental model. Reptiles represent the first amniotes. From stem reptiles, extant reptiles, birds and mammals have evolved. Mammal hairs and feathers evolved from Therapsid and Sauropsid reptiles, respectively. The early reptilian integument had to adapt to the challenges of terrestrial life, developing a multi-layered stratum corneum capable of barrier function and ultraviolet protection. For better mechanical protection, diverse reptilian scale types have evolved. The evolution of endothermy has driven the convergent evolution of hair and feather follicles: both form multiple localized growth units with stem cells and transient amplifying cells protected in the proximal follicle. This topological arrangement allows them to elongate, molt and regenerate without structural constraints. Another unique feature of reptile skin is the exquisite arrangement of scales and pigment patterns, making them testable models for mechanisms of pattern formation. Since they face the constant threat of damage on land, different strategies were developed to accommodate skin homeostasis and regeneration. Temporally, they can be under continuous renewal or sloughing cycles. Spatially, they can be diffuse or form discrete localized growth units (follicles). To understand how gene regulatory networks evolved to produce increasingly complex ectodermal organs, we have to study how prototypic scale-forming pathways in reptiles are modulated to produce appendage novelties. Despite the fact that there are numerous studies of reptile scales, molecular analyses have lagged behind. Here, we underscore how further development of this novel experimental model will be valuable in filling the gaps of our understanding of the Evo-Devo of amniote integuments.
\end{abstract}

KEY WORDS: stratum corneum, skin, hair follicle, skin regeneration, Turing, reaction-diffusion

\section{Introduction}

Among amniotes, stem reptiles were basal to extant reptiles, birds and mammals. When reptiles established themselves on land, their integuments had to adapt to the challenges of terrestrial life by developing barriers which can prevent water loss (Alibardi, 2003), mechanisms which can protect against ultraviolet (UV) irradiation and mechanical shields which can provide protection against the rigors of terrestrial life. Starting from these basic needs, different types of reptilian scales evolved in the Mesozoic period to serve different functions (Chuong et al., 2002) and adapt diverse species to different niches. As amniotes evolved toward endothermy, skin appendages related to heat conservation appeared (Wu et al., 2004). Hairs and feathers evolved from Therapsid and Sauropsid reptiles, respectively, as a result of convergent evolution (Fig. 1; Alibardi, 2003).

Although vertebrate skin appendages such as scales, feathers, hairs and teeth appear to be different, they share a number of common developmental pathways, such as the Hedgehog, bone morphogenetic protein (BMP) and Wnt signaling pathways. Variation and innovation in developmental processes are thought to be key mechanisms for forming different types of skin appendages (Chuong, 1998; Chuong and Homberger, 2003). The evolution of feathers and hairs possibly began from scales present in

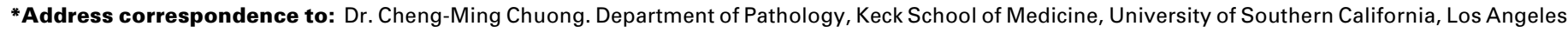

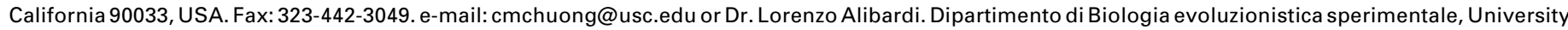
of Bologna, Bologna, Italy. e-mail: alibardi@biblio.cib.unibo.it
}

Published online: 9 June 2009.

ISSN: Online 1696-3547, Print 0214-6282

(c) 2009 UBC Press

Printed in Spain 
early reptiles in which the modulation and re-organization of gene regulatory networks led to new forms of skin appendages (Chuong, 1998; Wagner. 2007; Table 1). To thoroughly understand the origin and evolution of amniote skin appendages, we must include reptile scales in these analyses since the prototype reptile scales represent the basal state (see section on "Evo-Devo"). Reptiles may have obtained a periodic arrangement of scales early in evolution (see section on "Pattern Formation"), because this helps partition the unit of renewal and regeneration in an effective topo-biological configuration (see section on "Regeneration"). Subsequently, essential, novel evolutionary mechanisms to transform scales into feathers and hairs include the formation of follicular structures and the ability for proximal-distal elongation of filaments (Fig. 1; Chuong et al., 2000, 2003, 2007; Alibardi, 2003, 2004a; Prum, 1999; 2005; Sawyer and Knapp, 2003).

In this review, our objective is to provide a perspective that highlights the value of the reptile scale as an experimental model for furthering our understanding of the Evo-Devo of amniote integuments, biological pattern formation, and the different strategies of regeneration in amniotes. It is not intended to provide a detailed account of reptilian skin biology. Those interested in this topic can be referred to the more specific references on reptile integuments (Maderson, 1985; Landmann, 1986; Alibardi, 2003).

\section{Reptile scale types}

Here we will introduce the basic type of reptilian scales. Over time, diverse scale types evolved in the Mesozoic period (although some of the lineages involved are now extinct) and in extant reptiles. Some types with rather unusual characteristics are shown schematically in Fig. 2. An exemplary green iguana (Iguana iguana) with different types and arrangement of scales is shown in Fig. 3. Some unusual scales are shown in Fig. 4.
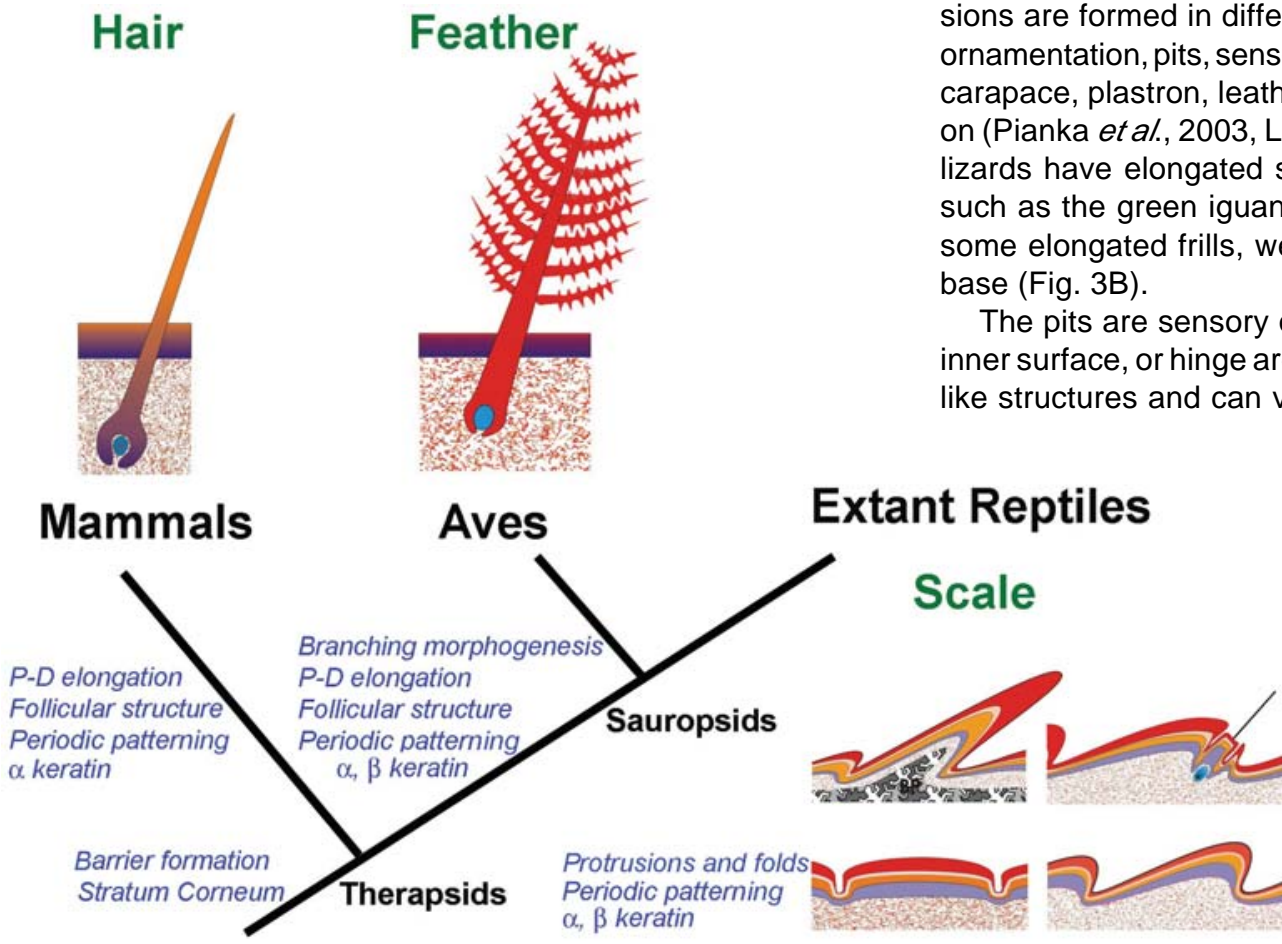

\section{Stem Reptiles}

Extant reptiles are represented by four orders: Crocodilia (alligators and crocodiles), Chelonia (tortoises and turtles), Squamata (lizards and snakes), and Rhynchocephalia (the tuatara or Sphenodon punctatus) (Alexander, 1970; Maderson, 1985; Landmann, 1986). Crocodilian scales show relatively few variations in gross morphology, are generally only a little overlapped and show a large surface composed mainly of hard $\beta$-keratinized, stratified epidermis (Alibardi and Thompson, 2000, 2001, 2002; Alibardi, 2003, 2006a, 2006b; Alibardi and Toni, 2006). The narrow hinge regions among scales have a thinner epidermis containing both $\alpha$ - and $\beta$-keratin. Chelonians have a soft, folded skin in the limbs, tail, neck (most aquatic turtles), and a scaled skin in the shell (Maderson, 1985; Alibardi, 2003). In limbs and tail of terrestrial turtles, hard scales containing $\beta$-keratin are also present, but $\beta$-keratin is decreased or absent in the hinge regions. A few layers of keratinocytes are covered by a thick, multi-layered corneus layer in the carapace and plastron.

In squamates, there are non-overlapping scales which do not appear to exhibit anterior-posterior polarity (Fig. 2A). They are seen in the scales on the head of snakes and lizards, and the round scales (tuberculate scales, Fig. 3F) on the sides of the body of the green iguana. However, the most frequently occurring is the overlapping scale, which has distinct outer and inner surfaces (Fig. 2B, 3 C-E). This is the most common scale type on the body of lizards and snakes. The overlapping scale is asymmetric, with the hinge region assigned to the posterior end. The outer surface consists of a strongly cornified epidermis, which provides stiffness for the scale. During embryonic development, the morphogenesis of overlapping scales passes through the flat two-layered epidermis stage, the symmetric scale anlagen stage, the asymmetric scale anlagen stage, and the $\beta$-keratinizing asymmetric scale stage (Maderson, 1985; Alibardi, 1996, 1998).

In different species, some overgrowths and / or skin protrusions are formed in different body regions. For example, microornamentation, pits, sensory receptors, spiny, horny, crest, scutes, carapace, plastron, leather-like, and mosaic head scales and so on (Pianka et al., 2003, Landmann, 1986; Wu et al., 2004). Some lizards have elongated scales in a specific region of the body, such as the green iguana crest (frill) on the back (Fig. 2, 3). In some elongated frills, we observe a follicle-like structure at the base (Fig. 3B).

The pits are sensory organs in reptilian scales located in the inner surface, or hinge area, of some scales. They display folliclelike structures and can vary in their extension and depth. How- 
A

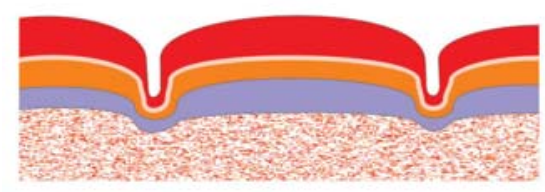

B
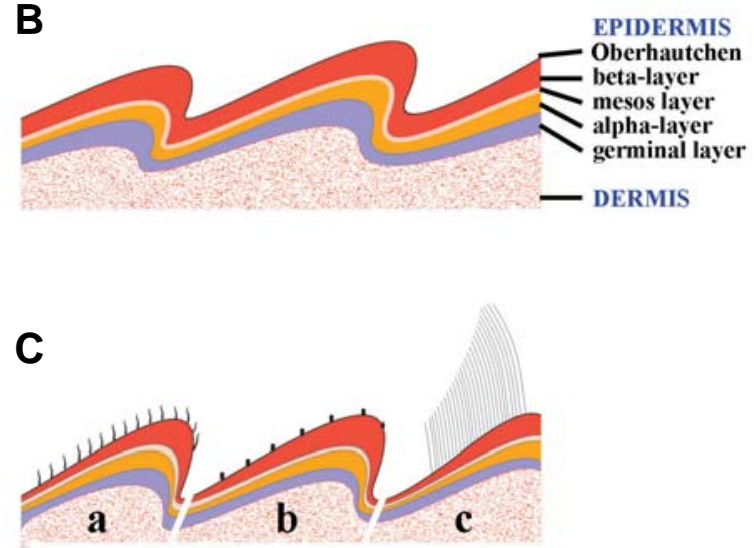

D

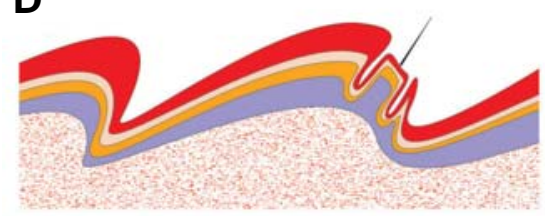

E

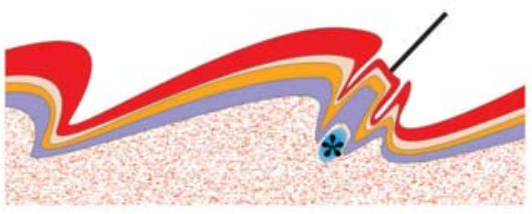

$\mathbf{F}$
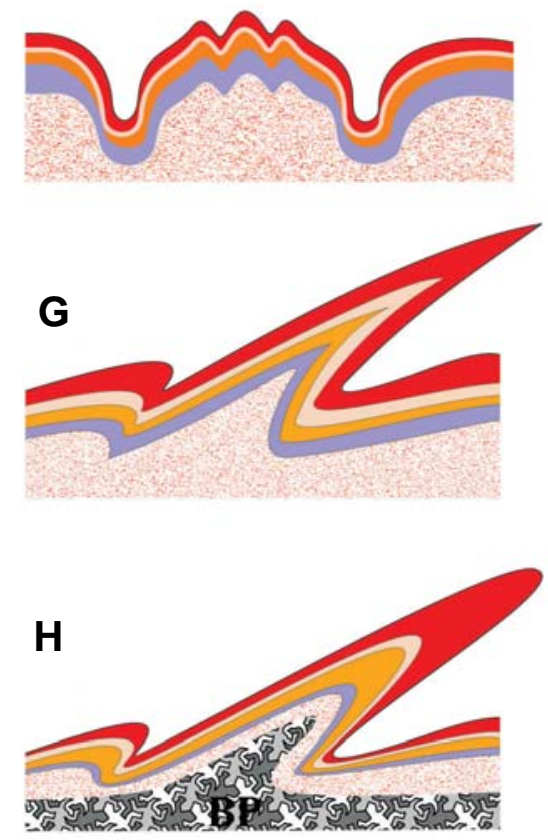

I

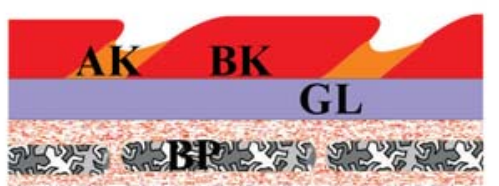

J

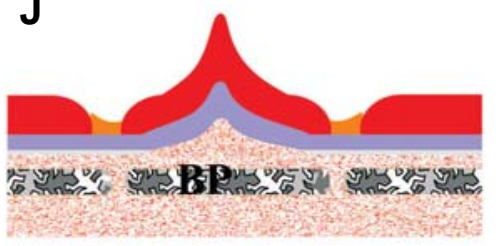

ever, they are different from the true follicles in hairs and feathers because the structures are essentially only epidermal without dermal participation (Fig. 2, 4, Maderson, 1972; Von During and Miller, 1979). For example, in some gecko-like lizards, they merely represent the elongation of a single Oberhäutchencell, with the onion-like termination of sensory nerves underneath the specific region where the hair-like organ is located (Maderson, 1985).

In other cases, terminal tactile sense organs contain a dermal component consisting of fibrocyte layers. There are also Merkel cells for mechanosensory function. Pits that contain sense receptor organs on the scales of Agama form in a special site of the scale tip, and consist of a unique epidermal outgrowth (Fig. 4G). Thus, while overlapping scales are more widespread, there are some unusual scale shapes and structures (Fig. 2, 4). Some may show features which are the preludes of proximal-distal elongation or follicle invagination (Fig. 1 ), but they do not cumulate in real appendage follicles as seen in hairs or feathers.

\section{Evo-Devo}

Initial adaptation to terrestrial life

The integument forms a critical interface between the organism and its environment. To live in the terrestrial environment successfully, reptilian an-

Fig. 2. Schematic drawings showing different types of reptile scales. Scales (resting phase) are shown in multiple layers with names labeled in panel B. (A) Non-overlapping tuberculate type scales. (B) Overlapping scales commonly seen in squamates. (C) Variations of microstructures from the Oberhäutchen layer illustrating short spines in $a, b$ and long setaes in c (such as those in the adhesive pad lamellae in geckos, Fig. 4B). (D) Pits on the scales of anole, gecko and iguana (mainly epidermal sensory organs; Fig. 4 E, F). (E) Tactile sensory organ on the hinge side of a scale in Agama. Some follicle-like structures have clustered dermal cells associated to their base; Fig. 4G). (F) Scales with ridges are seen on the back of skink or the neck of anole. (G) Frills, or very elongated scales, are seen on the back of iguana (Fig. 3B). (H) The horn on the head of chameleon contains a bony element core (osteoderm). (I) Scales on the limb of crocodilians show only minor overlapping. (J) Keeled scales with a central, elevated corneous ridge are seen on the dorsal body of crocodilians and some armored agamid lizards (e.g. Australian spiny desert lizard or molok). Legends: a, fine 'hair' on scales of anoles; $b$, Micro-ornamentation on scales of snakes; $c$, Toe pad of anole or gecko; *, dermal cells clustered at the base of sensory organs in Agama; $A K, \alpha$ keratin; $B K, \beta$ keratin; $B P$, bone element.

TABLE 1

COMPARISON OF REPTILE SCALES, AVIAN FEATHERS AND MAMMALIAN HAIRS

\begin{tabular}{|c|c|c|c|c|c|}
\hline & Non-overlapping scales & Overlapping scales & Special scale types & Hairs & Feathers \\
\hline Keratin & Alpha, beta & Alpha, beta & Alpha, beta & Alpha & Alpha, beta \\
\hline Elongation & No & Yes, but very limited & longer & Can be very long & Can be very long \\
\hline Follicular structure & No & No & Primitive? & Yes & Yes \\
\hline Stem cells & No & ? & ? & Hair bulge & Follicular bulge \\
\hline Proliferating cells & Random & $\begin{array}{l}\text { Diffuse in general with some cells } \\
\text { preferentially distributed }\end{array}$ & $?$ & Localized in the proximal follicle & Localized in the proximal follicle \\
\hline Dermal papilla & No & No & Some proto-dermal condensation? & Yes & Yes \\
\hline $\begin{array}{l}\text { Structure of } \\
\text { appendages }\end{array}$ & $\begin{array}{l}\text { Epithelial layer covering a } \\
\text { dermal core }\end{array}$ & Epithelial layer covering a dermal core & Depending on different examples & Epithelial cord & $\begin{array}{c}\text { Epithelial layer with mesenchymal } \\
\text { core lost when mature }\end{array}$ \\
\hline Regeneration & Sloughing renewal cycle & Sloughing renewal cycle & ? & Episodic molting and regeneration & Episodic molting and regeneration \\
\hline
\end{tabular}



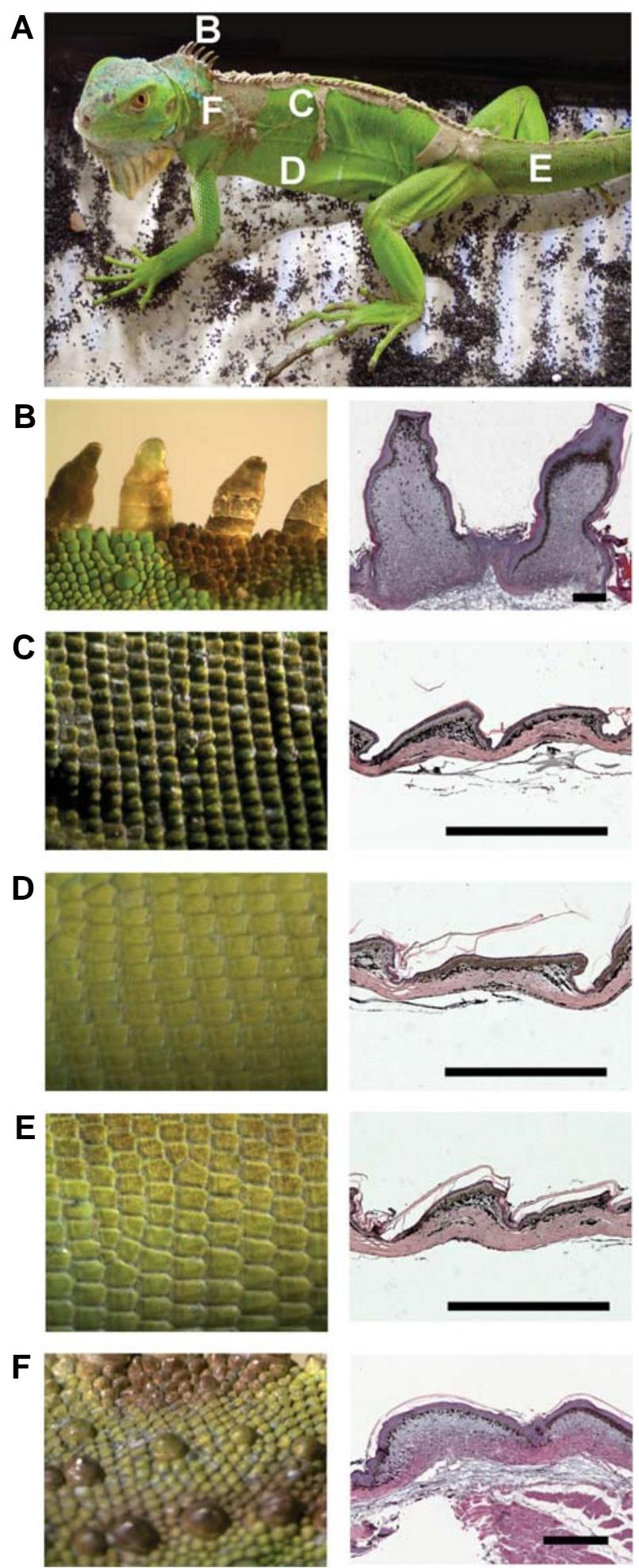

Fig. 3. Arrangement and different types of scales in iguana. (A) An adult iguana showing different scale types in different regions. (B-F) Left column: scales from regions designated in (A). Right column: H\&E staining of their histological sections on the right. (B) Frills from the midline of the neck. Note the elongated scales compared with those in (C-F). (C) Scales from the dorsal trunk. (D) Scales from the ventral trunk. (E) Scales from the tail. (F) Tuberculate scales from the lateral neck region. Scale bars, $500 \mu \mathrm{m}$. cestors had to deal with the huge differences between land and the aquatic environment (Alibardi, 2003). The major challenge was the production of a barrier in the skin that limited the loss of water by transpiration or evaporation. There was also the need to deal with the intense UV irradiation of the land environment and to provide mechanical protection on the rough terrestrial environment, much harsher than the aquatic environment of the amphibian ancestors of reptiles. The skin of reptiles responded to these challenges in the following ways.

1. Development of a barrier to prevent water loss to the external environment. The mesos- and $\alpha$-layers of the extant squamate epidermis played key roles in the development of this barrier (Bentley et al., 1966; Davis et al., 1980; Dunson and Mazzotti, 1988; Landmann, 1979, 1986; Landmann et al., 1981; Lillywhite and Maderson, 1982; 2006; Menon et. al., 1986, 1996; Lillywhite, 2006). Formation of a corneum barrier involves the synthesis of cornified proteins such as loricrin-like proteins and complex lipids and waxes. 2. Development of a radiation resistant mechanism to prevent the skin from being damaged by UV irradiation. The latter process in Squamates is obtained by biochemical, morphological and physical mechanisms (Chang, 2003; Ringvold, 2003). 3. Development of a tenacious skin shield, both in the epidermis and in the dermis, to prevent mechanical damage from the harsh terrestrial environment. Hard proteins ( $\beta$-keratins or sKAPs) (KAP: keratin associated proteins) have been the solution to this problem in reptiles and birds (Landmann, 1986; Maderson and Alibardi, 2000; Maderson, 2003; Alibardi et al., 2007; Toni et al., 2007). 4. Development of an effective heat insulation mechanism to live in an environment in which the range of temperatures experienced daily or seasonally can be huge. In this regard, reptiles have not been very successful and their daily and annual activities are thus limited (Pianka and Vitt, 2003). 5. Development of different adaptive structures related to special environments. For example, various sensory functions have developed on the skin with a pit-like morphology (Von During and Miller, 1979; Cooper and Greenberg, 1992; Pianka and Vitt, 2003; Landmann, 1986).

\section{Molecular evolution of $\alpha$ - and $\beta$-keratin}

There are two main types of intermediate filament proteins in vertebrate keratinocytes: $\alpha$ - and $\beta$-keratins. Reptiles have both $\alpha$ and $\beta$-keratins. $\alpha$-keratogenic tissue provides a barrier to water loss while an overlying $\beta$-keratogenic layer provides mechanical stiffness to the skin (Alexander, 1970; Baden et al., 1970, 1974; Fraser and Parry, 1996; Gregg and Rogers, 1986; Landmann, 1986; Maderson, 1985; Presland et al., 1989a, 1989b; Carver and Sawyer, 1987; Sawyer et al., 2000; Steinert and Freedberg, 1991; Alibardi et al., 2002, 2005; Alibardi, 2000, 2001, 2002a, 2002b; Alibardi and Toni, 2006; Wyld and Brush, 1979, 1983).

$\alpha-$, or "soft" keratin, is present in all vertebrate species whereas $\beta$-, or "hard" keratin, is present only in birds and reptiles. Overlapping scales and the production of $\beta$-keratins provide strong protection (hard scales, ramphoteca, claws) but still allow some mechanical plasticity through the inter-scale regions which are made of $\alpha$-keratins. $\alpha$-keratins are divided into type I (acidic, 40 $55 \mathrm{kDa}$ ) and type II (basic to neutral, 56-70 kDa), and they form the $8-10 \mathrm{~nm}$ intermediate filament cytoskeletal network of epithelial cells. Previous studies have shown that in lizard epidermis, acidic and scarse basic cytokeratins, similar to those of the 
mammalian epidermis, are present (Fuchs and Marchuk, 1983; Alibardi, 2000, 2001; Alibardi and Toni, 2006). $\alpha$-keratins in lizards, snakes, tuatara (Sphenodon punctatus), chelonians, and crocodilians comprise 5-8 low molecular acidic type components (40-65 kDa) and 5-6 higher molecular neutral-basic types (45-68 kDa) (Alibardi and Toni, 2006; Toni et al., 2007; Toni and Alibardi, 2007). Although the general characteristics and components of $\alpha$ keratins in different reptilian groups have been identified, no molecular data on their amino acid sequences or genetic structure are presently available.

$\beta$-keratins in reptiles consist of the lower molecular components of corneous proteins (lepidosaurians, 12-18 kDa; chelonians, 13-18 and 22-24 kDa; crocodilians, 14-20 kDa). Proteins above $25 \mathrm{kDa}$ are probably polymerized $\beta$-keratins or aggregates. $\beta$-keratins are mainly basic while acidic and neutral $\beta$-keratins may derive from post-translational modifications. $\beta$-keratins are ultra-structurally represented by 3-4 nm electron-lucent filaments,

A
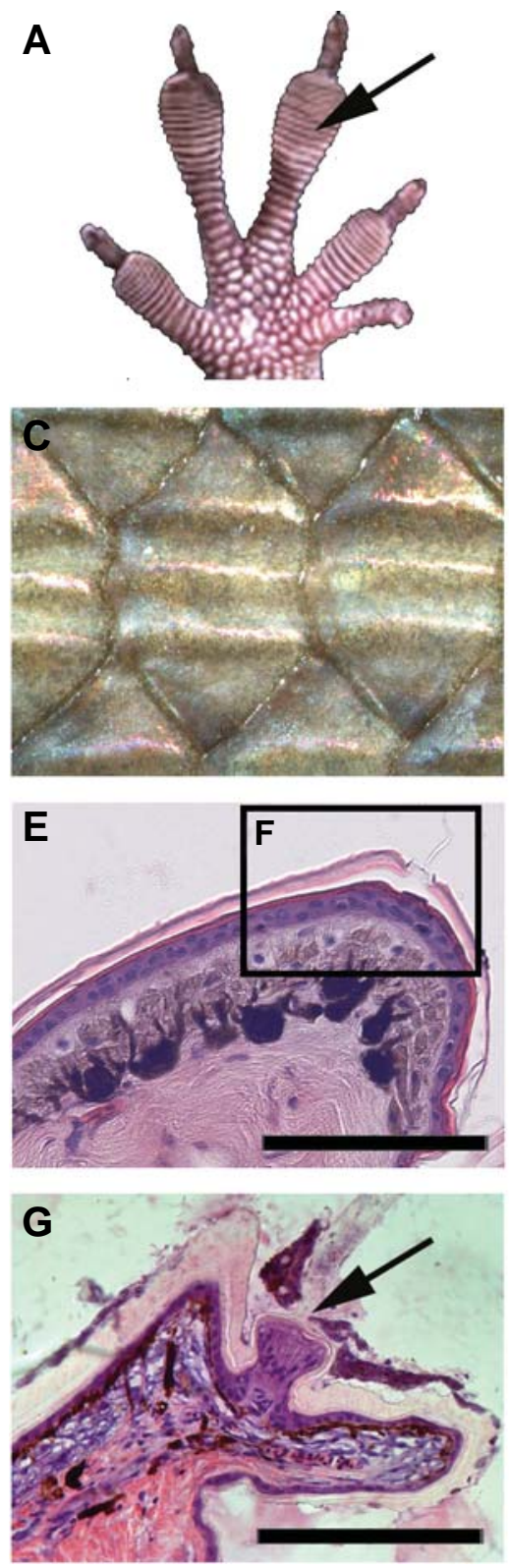

embedded in a matrix of moderate electron density (Maderson, 1985; Landmann, 1986; Alibardi, 2006a).

Recent molecular biology and proteomic studies have sequenced some genes and proteins as $\beta$-keratins (Dalla Valle et al., 2005, 2007). These molecules comprise glycine-proline-rich and cystein-proline-rich proteins of 13-19 kDa. $\beta$-keratin genes may or may not contain introns and are present in multiple copies with a linear organization, as in avian $\beta$-keratin genes. Despite amino acid differences towards the $\mathrm{N}$ - and $\mathrm{C}$-terminals, all $\beta$ keratins share high homology in their central, $\beta$-folded region of 20 amino acids, which has been indicated as the core-box. This is the region where two close $\beta$-keratin sequences are present, and this region is implicated in the formation of $\beta$-keratin filaments of scales, claws, and feathers (Gregg and Rogers, 1986; Brush, 1993; Fraser and Parry, 1996). The homology of the core-box among different species of reptiles suggests that these proteins evolved from a progenitor sequence present in the stem of reptiles where the core box was already established. In birds, a small $\beta$-keratin, also containing a core box, has allowed the formation of feathers.

Reptiles and birds have both $\alpha$ - and $\beta$-keratins (Shames etal., 1989; Chondanker etal., 2003; Yu etal., 2002; Whitbread et al., 1991), while mammals only have $\alpha$-keratins. Molecular studies suggest that $\beta$ keratins in reptiles and birds occupy a functional role analogous to that of mammalian keratin associated proteins (mKAPs, Rogers, 2004). Furthermore, their molecular weight, amino acid composition, and mechanism of polymerization is completely different from those of $\alpha$-keratins. Therefore the proteins so far indicated as $\beta$-keratins seem to represent the reptilian equivalent of the keratin-associated or matrix proteins present in mammalian hairs, claws, and horns (Alibardi et al., 2007; Toni et al., 2007). These proteins have followed a completely different molecular evolution from $\alpha$-keratins, but may be phylogenetically more recent than $\alpha$-keratin. While $\alpha$-keratins appeared not later than the Cambrian period (around 570 million years ago; Fuchs and Marchiuk, 1983; Steinert and Freedberg, 1991), $\beta$-keratins appeared in a later evolution associated with the formation of the resistant corneous layers of stem reptiles. It is possible that genes coding for the $\beta$-keratin of feathers became expressed about 150-180 million years ago in archosaurians reptiles (theropods and birds), much later than those coding for the first $\beta$-keratins which might have appear in stem reptiles of the Carboniferous period, over 320 mya (Fig. 1; Alibardi, 2006b). Although no definitive information is presently available on the evolution of $\beta$-keratin

Fig. 4. Unusual scale types. $(A, B)$ Some scales have specialized surfaces to help them climb. (A) Toe pad of anole. (B) Longitudinal sections of digital pads shown in (A). Note the hairy structures on the setae are variations of the Oberhäutchen layer (Fig. 2C). (C,D) Some scales have dorsal ridges (keels) which increase the protective properties of the scales. (C) Dorsal skink scale with three ridges. (D) Cross section of an anole neck scale which exhibits one central ridge (Fig. 2F). (E-G) Some scales form pits, sensory organs with a simple structure at the dermal-epidermal junction (Fig. 2D). (E) Low power view of the distal edge of a scale. (F) Detail of the pit sensory organ in (E) (arrow indicates the sensorial filament derived from Oberhäutchen layer, Fig. 2D). (G) Agama tactile sensory organ. It shows more of a complex epidermal structure with a nerve terminal in its base (arrow). Scale bars, $100 \mu \mathrm{m}$. 
from the likely more primitive $\alpha$-keratin (Sawyer and Knapp, 2003), recent molecular studies have increased our understanding. These studies have indicated that basic amniotes possessed a common ancestral protein rich in glycine and proline sequences that diversified in the evolutive lineage leading to reptiles and birds versus that leading to mammals (Alibardi et al., 2007; Toni et al., 2007). In reptiles and birds, $\beta$-keratins were formed while in mammals high-glycine and high-sulfur proteins developed for this purpose. Both are small proteins that associate with $\alpha$-keratins to make a very hard corneous material, utilized for hard scales, claws, hairs, horns etc. With more genomes sequenced, further studies on the molecular evolution of $\alpha$ - and $\beta$-keratins, their associated proteins and other hard keratins will provide clues on amniote evolution.

\section{Scale as a basal state for feather and hair follicle evolution}

Scales, feathers and hairs are all skin appendages and, as such, they share some signaling pathway networks. One insightful experiment using reciprocal epithelial-mesenchymal recombination among developing lizard, mouse and chicken skins demonstrates this relationship (Dhouailly, 1975). The results showed that the epidermis of these animals can understand the message from dermis to "make an appendage". However, due to the lack of information in their genomes, when lizard epidermis is encountered with chicken mesenchyme, scales will form but arranged in feather arrays.

The origin and early evolutionary history of feather and hair is not clear, but there are several hypothetical models (Fig. 5; Brush, 1993; Prum, 1999; Chuong et al., 2000, 2003. Prum and Brush, 2002; Alibardi, 2004a,b,c). One key feature shared by the hair and the feather follicle is that both have adopted a proximal - distal growth mode. Another key shared feature is the invagination of the epidermis to form follicles, although produced via different developmental mechanisms. Both steps are important evolutionary novelties.

\section{From reptile skin to avian feathers}

Reptilian scales and avian feathers have been considered as homologous structures (Maderson, 1972). The epidermal cells which make feathers and avian scales arise from the same progenitors, suggesting that feathers evolved through modification of the embryonic epidermis (Sawyer and Knapp, 2003; Sawyer et al., 2005). However, there are some fundamental differences in the development of scales and feathers. Normal scales do not form follicular structures. The mature scales are made of an epithelial shell and a mesenchymal core (Wu et al., 2004). The outside of the epithelial shell is the suprabasal corneous (horny) layer.

Compared with reptilian scales, avian feathers have a much more complex topological organization (Yu et al., 2004; Lucas and Stettenheim, 1972). After the feather bud protrudes and elongates, the localized proliferation zone gradually shifts through the shaft and localizes proximally to the base of the feather (Chondankar et al., 2003). In the meantime, the epidermis surrounding the feather starts to invaginate into the dermis to form the follicle. The dermal papilla is situated at the base of the follicle, and induces the epithelial collar above to continue proliferation (Yue et al., 2005) and branch (Yu et al., 2002; Yue et al., 2006).

How were reptilian scales transformed into feathers? In a previous study, Regal (1975) suggested that reptilian scales first underwent elongation, later through etching of the elongated scales to produce the branched feather vanes, and finally the inter-woven pennaceous feather barbs became plumulaceous. The Triassic archosaur fossil, Longisquama, which exhibits branches in its elongated scale, appears to support this hypothesis (Jones et al., 2000). Yet, developmental and molecular evidence and fossilized feathers suggest that feathers evolved from conical hair-like outgrowths, with a cylindrical follicle (Prum, 1999; Prum and Brush, 2002; Chuong et al., 2000; Yu et al., 2002; Alibardi, 2006b).

Since the 1990's, some fantastic fossils have been discovered in Jehol Biota (120 million years ago) in northern China (Zhou et al., 2003). They are unique because the integument and appendages are well preserved due to the geology of that time (shallow lake with frequent volcanic eruptions in the vicinity). Some of these fossils are bona fide dinosaurs as judged by the skeleton, but there are feather-like appendages on their integument (Chen et al., 1998; Xu et al., 1999, 2001, 2003, Prum and Brush, 2002). Are they real feathers? Some are, and while some do not fulfill all the definitions of a true feather (Chuong et al., 2003), they do represent precursor appendages of feathers and can be named proto-feathers.

Laboratory experiments showed retinoic acid can produce feather growth on a scale (Dhouailly et al., 1980). Ectopic expression of $\beta$-catenin in the scale can cause a small region of the scale epidermis to become feather follicles (Widelitz et al., 2000). Suppression of BMP receptor activity and over-expression of delta can produce similar results (reviewed in Widelitz et al., 2003). However, the experimental observations have always been that a small proportion of scale epidermis is activated to become feather primordia. It invaginates to form a feather follicle, and together they become "feathery scales". Conversion of a whole scale into one feather, as predicted by Jones et al., 2000, is never observed. Rather, it appears that a small group of stem cells in the scale is activated by molecular perturbation and these cells go on to form a feather.

The levels of BMPs and Shh were shown to regulate the pattern of branching morphogenesis (relative amounts of rachis and ramus, Yu et al., 2002; Harris et al., 2002). When the anterior posterior Wnt 3 a gradient in bilaterally symmetric flight feathers is flattened experimentally, the feathers are converted into radially symmetric downy-like feathers (Yue etal., 2006). Together, these results shed light on how feathers were built stepwise in development and evolution through multiple evolutionary novelties over approximately 50 million years (Fig. 5A; Chuong et al., 2000, 2001, 2003; Prum, 1999, 2005; Prum and Brush, 2002).

\section{From reptile skin to mammalian hair}

Unlike the fantastic discovery of feathered dinosaurs and protofeathers in fossils (reviewed in Prum and Brush,; Chuong et al., 2003), so far, there have been no paleontological records to provide clues which can help elucidate the presumed evolutionary steps taken from reptilian scales to mammalian hairs (Spearman, 1964; Maderson, 1972; Alibardi, 2004a,b,c). Several hypotheses have been proposed as to the origin of hair (Fig. 5B). Maderson (1970, 1972; 2003) hypothesized that hairs arose from reptilian sensory appendages of the mechanoreceptor type (pitorgan) that were located in the hinge region of ancient reptiles. In 
some frill-type scales, they form follicle-like structures (Fig. 3B). It will be interesting to study the cell density and proliferation in these follicle-like structures to evaluate the specific kinetics of cell renewal and growth, and compare them with follicular patterns in both hairs and feathers. Morphologically, the structure of the pits is reminiscent of a follicle, based on the invagination of the epidermis and the adjacent dermal structure. However, real dermal papillae with characteristics analogous to those of hairs, or even feathers, have not been demonstrated in these reptiles. Unlike the follicle-like structure of the frill, the pit forms the folliclelike structure from part of a scale. However, the cell behavior of pit formation, such as cell proliferation and regeneration, is totally unknown. The mechano-sensory role of the proto-hairs may have been gradually replaced by thermal insulatory function and contributed to successful endothermy. The multiplication of protohairs may have been caused by mutations leading to the increase of hair density which can provide improved mechanical protection and insulatory function. Certain mutations in the molecular pathways involved in appendage patterning might have resulted in the expansion of sensory bristles throughout the animal body surface.

On the other hand, Dhouailly and Sun (1989) have proposed a different model (Fig. 5B). The tongue is considered as one of the integuments. By comparing the topology and keratin types of scales and hairs with those of filiform papillar taste buds, they suggested that gradual changes in the expression of keratins in the inner surface of the scale epidermis might have led to a transformation of the scale structure from a hemi-cylindrical form to the more completely cylindrical structure found in hairs. This progression could have been the origin of hair follicle invagination.

Alibardi has provided another view with focus on the dermal side (Alibardi, 2004a-c). The variation in areas of dermal-epidermal interactions in the skin during evolution in different amniotes has been hypothesized to have led to the origins of scales, hairs and feathers. According to this hypothesis, based on extensive comparative observations over reptilian scales, feathers and hairs, reptilian scales show extended papillae beneath the outer scale surface where the hard, $\beta$-keratin layer is formed. Therefore no dermal condensation is generally seen during scale morphogenesis in reptiles. Based on the supposed derivation of feathers from scales, it is hypothesized that the progressive reduction of the outer surface of reptilian scales has restricted the morphogenetically active dermis previously associated to these areas, into smaller "niches", forming cell condensations indicated as dermal papillae. Hairs are hypothesized to have derived from an invagination of the morphogenetically active mesenchyme near hinge regions of scales of reptilian ancestors (synapsids), which led to

A

add barbule

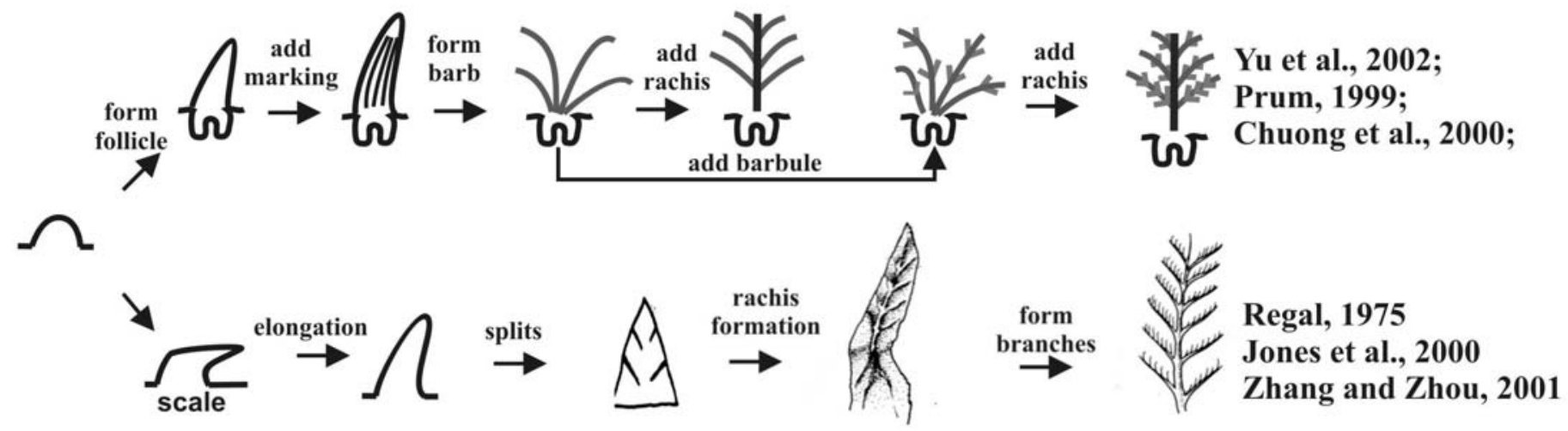

B formation of
sensory bristle
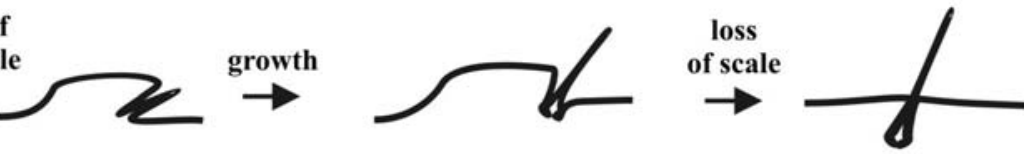

Maderson, 1972; 2003
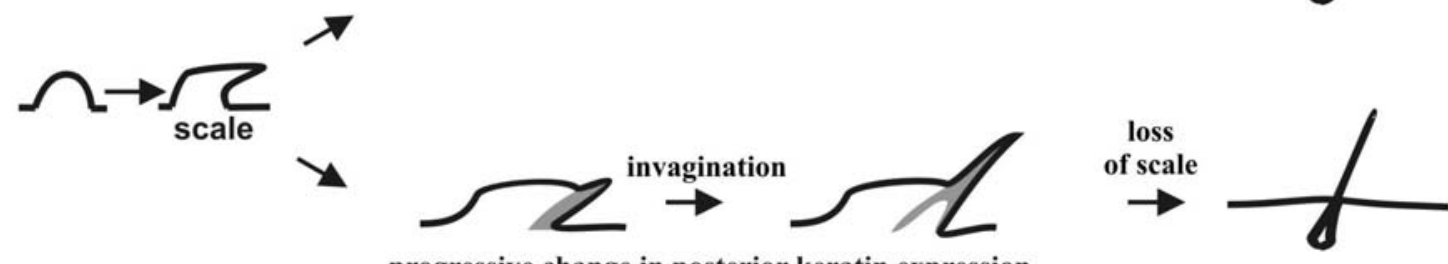

Dhouailly and
Sun, 1989

progressive change in posterior keratin expression

Fig. 5. Possible models for feather and hair evolution. (A) Possible models for the evolution of feathers. Experiments show that the barb - rachis model is correct. (B) Possible models for the evolution of hairs. The pit-like structures are shown in Figs. 2 and 4 . This drawing is from Fig. 6 B, C of Wu et al., 2004. 
A

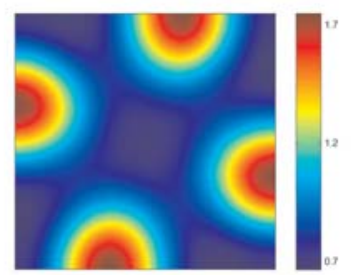

F

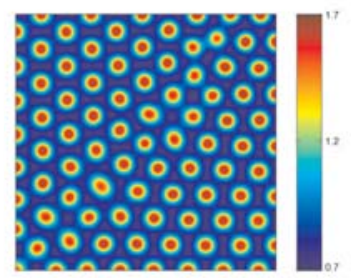

B

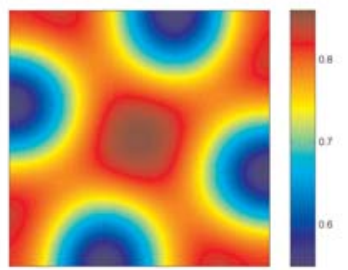

G

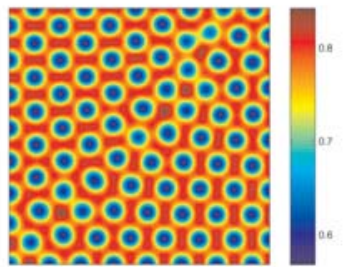

C

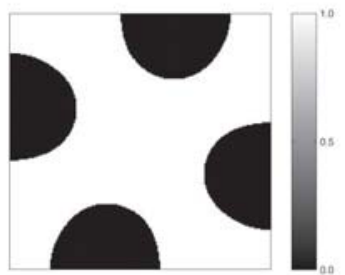

H

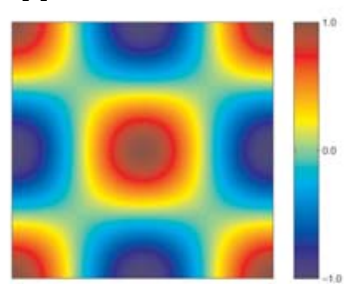

D

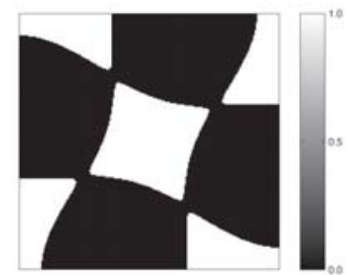

I

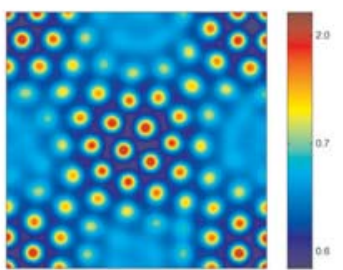

E

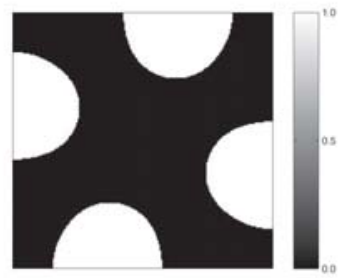

J

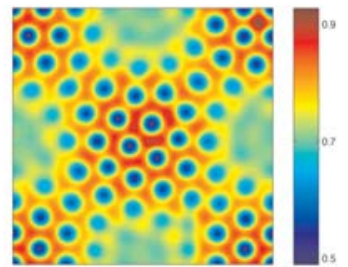

Fig. 6. A hypothetical model for reptile scale pattern formation, illustrating the effects of different concentrations and with possible involvement of both epithelium and mesenchyme. Numerical solution of a patterning model, as outlined in the Supplementary Information. We assume that a reaction-diffusion model with Schnakenberg-type kinetics (Schnakenberg, 1979) can be used to describe the concentration of two chemicals $\mathrm{v}$ and $\mathrm{w}$ in the epidermis. (A,B) The concentration profiles of $\mathrm{v}$ and $\mathrm{w}$ respectively, using the parameter values given in Table 2 (column 3), with no interaction from the dermis. (C-E) illustrate possible pattern profiles that could arise depending on the threshold level chosen for differentiation. (F,G) The concentration profiles of $\mathrm{v}$ and $\mathrm{w}$, respectively, using the parameter values given in Table 2 (column 4 ), with no interaction from the dermis. (H) Spatial map of the pattern assumed to form in the dermis (Shaw and Murray, 1990). (I,J) Results of numerical solution of the model with interaction from the dermis: it is assumed that production of the chemicalv is perturbed according to the patterning shown in (C). We see that the wavelengths of each pattern combine to form a more complex arrangement than in either of the individual cases shown in $(F, G, H)$.

the formation of the dermal papilla associated with hair.

With regards to keratin evolution, early theropsid amniotes, including mammalian ancestors, never possessed and later lost $\beta$-keratogenic tissue. Their $\alpha$-keratogenic epidermis was toughened by the evolution of mammalian-type HRP (histidine-rich protein, mainly filaggrins) (Maderson, 2003) and their hard derivatives, such as hairs, claws and horns, evolved specialized types of KAPs, rich in glycine-tyrosine or in cysteine (Rogers, 2004; Alibardi et al., 2007).

\section{Pattern Formation}

\section{Scale pattern: size, number, arrangement}

The arrangements of reptile scales and pigment patterns in different species are so exquisite, specific and stable, they are usually used as characteristics for the classification of species in vertebrates (Landmann, 1986; Pianka et al., 2003). Interestingly, scales also show regional specificity with different sizes and arrangements in different parts of the body surface (for example, the green iguana in Fig. 3). Because most scales do not elongate too much in length, the patterns are usually exquisite and obvious, without being obscured as in hair or feather filaments, making them a good model for the study of biological pattern formation. In contrast to other types of patterns observed in the skin, such as those of leopard and other vertebrate species, lizard or snake skin is relatively accessible experimentally and thereby providing us with paradigm systems for furthering our understanding in this area.

\section{Models}

One of the first mechanisms suggested for self-organized biological pattern formation was that of diffusion-driven instability put forward by Turing (Turing, 1952). The model postulates that two chemicals, reacting and diffusing on some domain, may form spatially heterogeneous patterns of chemical concentration provided certain constraints are satisfied. Subsequent cell differentiation is assumed to take place according to local chemical concentration levels, with discrete cell fates assumed to have arisen via exposure to differing thresholds. Turing's reactiondiffusion model has been suggested as a mechanism for many types of biological patterning, including fish pigmentation (Kondo and Asai, 1995; Painter et al., 1999; Kondo et al., 2009, this issue), feather bud, scale and hair follicle formation (Jung et al., 1998; Lin et al., 2006,; Nagorcka, 1983-1984; Nagorcka and Mooney, 1982; Sick et al., 2006; reviewed in Maini et al., 2006), amongst others.

Within this class of model, the size, number and arrangement of the pattern formed is dependent on the relative diffusion rates of the chemicals, their manner of interaction, and also the concentration thresholds supposed to elicit diverging paths of cell differentiation. For example, Fig. 6 (panels A,B and F,G) are the results of numerical simulation of a reaction-diffusion model, as outlined in the footnote of Table 2, and show a regular arrangement of peaks and troughs in chemical concentration. (C-E) illustrate possible patterning profiles that may arise with different threshold levels for cell differentiation in $(A),(B)$. It is clear from investigation of the models that pattern arrangement, inter-element spacing and shape can be controlled by variation of the factors described above, and lead to a diverse range of patterns from a single underlying mechanism. Murray has suggested that the differences in coat markings on different giraffe species may occur as a result of varying differentiation thresholds (Murray, 1988).

Following Turing's original model, other mechanisms for pattern formation have been suggested based on the chemotactic 
ability of cells to respond to their environment. The most wellknown models for cell-chemotaxis were proposed by Patlak (Patlak, 1963) and Keller and Segel (Keller and Segel, 1970). The underlying mechanism involves cells moving up gradients in chemical concentration (chemotaxis) and amplification of these gradients as cells secrete the chemical. As with the reactiondiffusion model, spatially heterogeneous patterns of chemical concentration may arise, and these are mirrored by patterns in cell density.

Murray and co-workers suggested such a model for the patterns of pigmentation seen on snake skin (Maini et al., 1991; Murray and Myerscough, 1991). They showed that by variation of the model parameters and domain size, many of the patterns found in different species of snake could be isolated. Fig. 7 illustrates a subset of these patterns: $(A-E)$ show the changes in pattern as different wave lengths are isolated in the models whilst $(\mathrm{F}-\mathrm{H})$ show a sample of the different pigmentation patterns that could arise from $(E)$ as the differentiation threshold changes. The effects of growth may also be incorporated into the models, as investigated by Painter and co-workers in the angelfish Pomacanthus (Painter et al., 1999).

The most recent model to be proposed for spatial pattern formation was the mechano-chemical model of Oster, Murray and Harris (Oster et al., 1983). Here, interactions between cells and the extra-cellular matrix (ECM) are supposed to lead to the generation of forces as cells adhere to the ECM. Once again spatially heterogeneous patterns of cell density and ECM may form under the right conditions. Each of the reaction-diffusion, cell-chemotaxis and mechano-chemical models are discussed in more detail elsewhere in this issue (Baker et al., 2009).

There is increasing biological evidence that the formation of skin integuments arises due to the interaction of events occurring in both the dermis and epidermis. Tissue interaction models assume that different pattern forming mechanisms are at work in each layer. Each model mechanism outlined above is only capable of generating simple spatial patterns. However, it is possible that the interaction of multiple mechanisms, from one layer or multiple layers, or present only in one region but not the other, may generate regional specific complex patterns.

We use a simple example to illustrate this possibility. We assume that patterning events occur in the dermis on a very fast time scale compared with those in the epidermis. In this way we may suppose that the effects of interaction can be captured in a reaction-diffusion model for the epidermis with the addition of a spatially varying source term for one chemical (Shaw and Murray, 1990). Fig. 6 illustrates possible patterns that may arise with these more complex models using the system outlined in the footnote of Table 2. Fig. 6 F, G show the results of numerical simulation of the model with no interaction from the dermis: a regular arrangement of peaks and troughs in chemical concentration arise from an initially homogeneous field. Fig. $6 \mathrm{H}$ shows the pattern supposed to form in the dermis and Fig. $6 \mathrm{I}, \mathrm{J}$ show the results of numerical simulation of the model with interaction from the dermis included. The superposition of pattern with a wave length of that in the dermis is clearly visible in the pattern arising in the epidermis.

We have illustrated, here and elsewhere in this issue (Baker et al., 2009), that the reaction-diffusion, cell-chemotaxis and mechano-chemical models are capable of generating a wide range of patterns, with varying size, number and arrangement, by simple manipulation of model parameters and variation of differentiation thresholds. Hence, the regional specificity of skin integuments may be well-explained by this class of models.

In the future it is important that molecular components of the biological system be identified with theoretical variables of the mathematical models in order to allow the models to be tested and refined. In turn, the models can be used to generate hypotheses and experimentally testable predictions and drive forward our knowledge of the mechanisms underlying skin integument formation.

\section{Regeneration}

\section{Physiological molting}

Among amniotes, the scales of reptiles have to interact with the harsh terrestrial environment, which can produce much wearand-tear. How to maintain an intact integument via epidermal homeostasis of stem cells, transient amplifying cells and differentiated cells became a new challenge. To this end, early reptiles have developed two different strategies. One is the continuous renewal model as seen in mammalian epidermis. This mode is adopted by most chelonians and crocodilians. The other model is episodic shedding of their epidermis, as seen in crustaceans, among invertebrates. This mode is adopted by lepidosaurian reptiles (Maderson, 1965, 1966, 1968, 1985; Landmann, 1986; Maderson et al., 1998; Alibardi, 1999, 2006a), and the mechanism must have survived evolution selection because it provides an effective method to replace worn epidermis.

The histological events during these episodic sloughing cycles have been elucidated in squamates (lizards and snakes)

TABLE 2

\section{PARAMETER VALUES USED IN THE NUMERICAL SIMULATIONS}

\begin{tabular}{clcc} 
Parameter & Description & Value $(\mathbf{A})-(\mathrm{E})$ & Value $(\mathbf{F})-(\mathrm{J})$ \\
\hline 1 & Production of 1 & 0.250 & 0.250 \\
2 & Production of 2 & 0.750 & 0.750 \\
3 & Diffusion rate of 3 & 0.230 & 0.195 \\
4 & Diffusion rate of 4 & 5.000 & 3.961 \\
5 & Perturbation wave number & 20.000 & 0.122 \\
6 & Strength of interaction & 0.000 & -0.030 \\
7 & Size of domain & 10.000 & 51.363 \\
\hline
\end{tabular}

The mathematical model considered for patterning in the dermis was of Schnakenberg form (Schnakenberg, 1979)

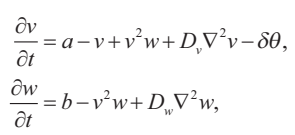

where the concentrations of chemicals $V, W$ are represented by $v, w$, respectively, and $a, b, \delta, D_{v}, D_{w}$ are positive constants. The term $\delta \theta$ represents interaction with the underlying dermis, with $\theta$ representing dilation of the extracellular matrix.

The system has spatially uniform steady states of the form

$v_{0}=a+b$,

$w_{0}=\frac{b}{(a+b)^{2}}$

We investigate the behavior numerically by supposing that the final steady state pattern generated by the mechano-chemical model in the dermis is of the form (Shaw and Murray, 1990) $\theta \sim \cos \left(K_{m} x\right) \cos \left(K_{m} y\right)$

Numerical simulations were carried out in two spatial dimensions using CoMSOL MULTIPHYSICS with the parameter values listed in Table 2. Zero flux conditions were implemented along each boundary and in each case the initial condition was a wave-like perturbation to the uniform steady state with wave number $K_{n}$ 
A

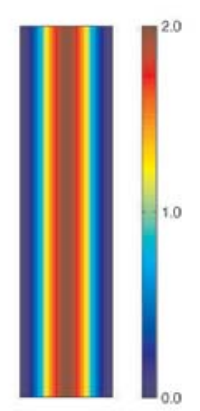

B

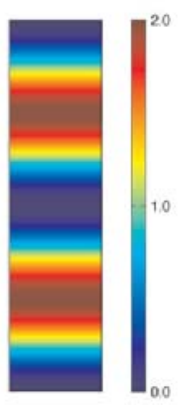

C

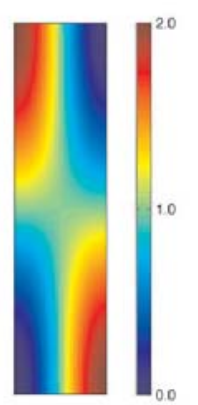

D

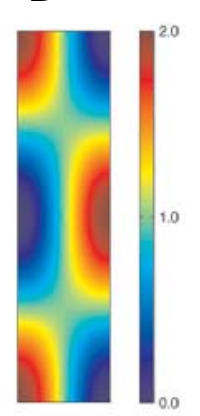

E

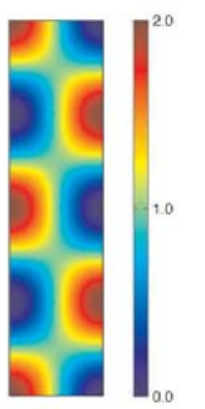

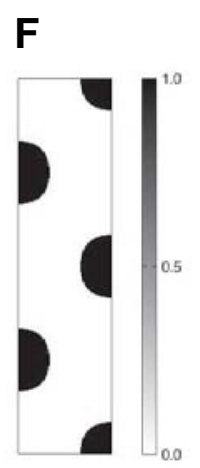

G

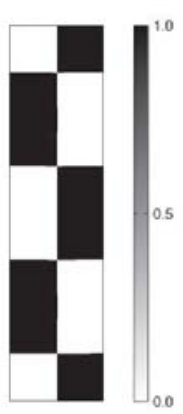

H

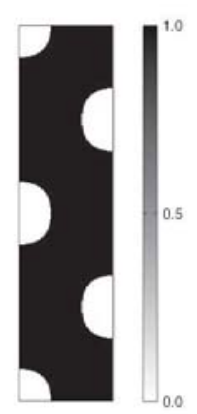

Fig. 7. A hypothetical model for snake pigmentation patterns. This is based on the cell-chemotaxis model proposed by Murray and co-workers (Mainiet al., 1991; Murray and Myerscough, 1991). (A-E) The various patterns produced when different modes are isolated by suitable choice of model parameters. (F-H) Possible pigmentation patterns that may arise through variation of the differentiation threshold corresponding to (E). The diagrams were produced by plotting periodic functions taking wave numbers calculated in Maini et al. (1991) and Murray and Myerscough, (1991).

(Maderson, 1965, 1966; Maderson and Licht, 1967; Landmann, 1979). From the germinal layer, different types of keratinocytes are produced, and they initially accumulate $\beta$-keratin and later $\alpha$ keratin to form a vertically alternated $\beta$ - $\alpha$ keratin epidermis (Fig. 8 ). The first layer to be formed is the micro-ornamented Oberhäutchen, followed by the $\beta-$, mesos-, and $\alpha$-layers. The latter is distinguished in the cornified $\alpha$-layer, the lacunar layer and a clear layer. The clear layer participates in the formation of the shedding complex, in conjunction with the new (inner) Oberhäutchen layer of the epidermis which is produced underneath the old one, the inner epidermal generation (Fig. 8).

The whole sloughing cycle can be divided into two phases, consisting of six stages (Fig. 8A). The first phase is the resting phase (stage 1). This phase can be further divided into the immediate post-shedding phase, the perfect resting phase, and the pre-renewal phase. In this article, we designate these three phases as stage $1 \mathrm{a}, 1 \mathrm{~b}$ and $1 \mathrm{c}$. The second phase is the renewal phase (stages 2, 3, 4, 5, 6) (Maderson, et. al. 1985; Landman, 1986).

In the perfect resting phase, the epidermis is typically composed of four layers of keratinocytes, which have fully differentiated. Cells are dead but the mechanically strong keratin scaffolds remain. In order, from outside in, these layers are known as the Oberhäutchen layer, $\beta$-layer, mesos layer and $\alpha$-layer. At the base is one layer of live cells, i.e., the basal layer or (germinal layer) (Fig. 8). In both post-shedding and pre-renewal phases some suprabasal cells are present.

In the renewal phase, the epidermis undergoes synchronous cell proliferation to expand the stratified layer. Differentiation events are duplicated in temporal order, with the formation of an intra-epidermal shedding layer (Maderson et al., 1998). Thus a quite complex eleven layer-stratified epidermis is formed, which can be divided into outer epidermal generation and inner epidermal generation (Fig. 8B). The outer epidermal generation now consists of, from outside in, an outer Oberhäutchen, outer $\beta$-layer, outer mesos layer, outer $\alpha$-layer, lacunar tissue and a clear layer. The inner epidermal generation now consists of an inner Oberhäutchen, inner $\beta$-layer, inner mesos layer, partially formed inner $\alpha$-layer and a basal layer.

The most interesting aspect of this phenomenon is to reexamine it with the concept of current cell biology and to identify the cellular events taking place in each stage. This will set the stage for further molecular analysis of the molecular mechanisms regulating each event. We can focus on three event stages (Fig. $8 \mathrm{~B}$ ). In the late resting phase (stage $1 \mathrm{C}$ ), when epidermal cells are ready to come out of "rest" and form the new generation of the epidermis, there is active cell proliferation. In stages $2-4$, the major event taking place is the specification of different layers. Cell divisions are likely to be asymmetrical and the mitotic axes are likely to be vertical to the basal layer. Hence new supra-basal layers are generated. In stages 5-6, the major event is that terminal differentiation takes place in each specified new layer.

There is one key difference between the lizard epidermis and mammalian epidermis. In mammalian epidermis, the basal layer generates cells that make up the spinous, granular and corneal layers. These different layers represent different stages of keratinocyte life, and a single keratinocyte has to go thorough all these stages. In lizard epidermis, different layers (Oberhäutchen, $\beta$-layer, mesos, $\alpha$-layer) are generated and specified in temporal order. A keratinocyte will become one layer or the other. It would be very interesting to find out which molecular pathway is used to perform this cyclic specification mechanism.

Growth control in episodic renewal epidermis is complicated. The rate of cell proliferation varies from a low level (resting phase) to a high level (renewal phase) (Maderson, 1970; Flaxman, 1972). Few cell proliferation and differentiation events take place during the perfect resting condition period (Flaxman and Maderson, 1973; Landman, 1986). As the renewal phase starts, complex coordination between cell proliferation and differentiation provides an excellent opportunity to study the coordination of cell cycle genes, signaling molecules, cytoskeletal assembly, and formation of barriers. The sloughing cycle also represents another example of stem cell activity under biological rhythm control (Plikus and Chuong, 2008; Pilkus et al., 2007, 2008, 2009 this issue). Study of this temporal control may also provide us with clues as to the origin of hair and feather cycling.

\section{Different strategies of skin appendage regeneration}

In amniote integuments, there are different ways to maintain homeostasis and to respond to injures and regenerate. Proliferating cells in reptilian scales are more diffusely distributed in developing scale primordia (Tanaka and Kato, 1983) and mature scales (Alibardi, 1996, 2003). As a result, most scales are only elevations above the skin surface. Some have become asymmet- 
ric and elongate mildly to form overlapping scales (Figs. 2 and 4), but rarely do they form very elongated appendages.

One of the key features shared by hairs and feathers, but not scales, is their ability to form follicles with growth zones localized at the proximal end (Prum, 1999; Chuong et al., 2000, 2003, Chondankar et al., 2003; Table 1). This follicular structure allows a skin appendage to add new cells at the proximal end, whilst elongating at the distal end. Stem cells and TA cells, matrix for hairs and collars for feathers, are well protected in the follicle under the skin surface (Yue et al., 2005; Cotsarelis, 2006; Chuong et al., 2007). Within the follicle, TA cells, and differentiated cells (hair and feather filaments) have to achieve homeostasis, and their relative positions may affect the shapes and symmetry of the filament (Yue et al., 2006). When the filaments need to be replaced, or when there is a need to change animal appearance by changing fur coats or plumages, this topological arrangement allows the filaments to be shed without losing stem cells and the signaling centers, the dermal papillae. Thus the follicle configuration, evolved independently for hairs and feathers, allows for new strategies in the growth and regeneration of skin appendages.

Since the skin is at the interface of the organism and its external environment, it is continuously worn and torn. A single layered epithelium will not be able to accommodate this treatment. With the formation of stratified epithelium, one straightforward strategy is the continuous replacement of epithelial cells. The basal layer generates new cells, which then differentiate and become suprabasal cells (basal layer $\rightarrow$ different supra-basal layers sequen-

A

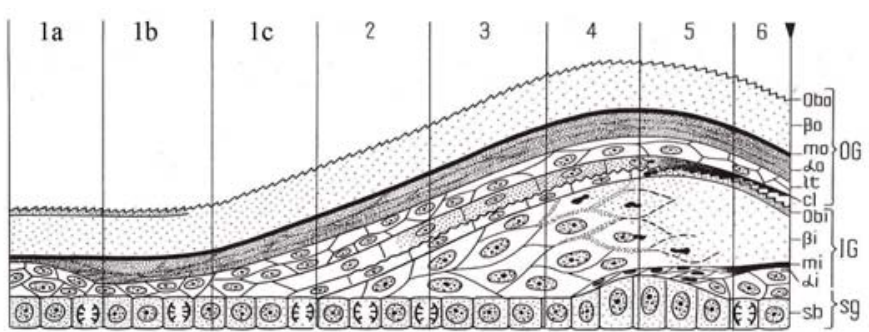

B

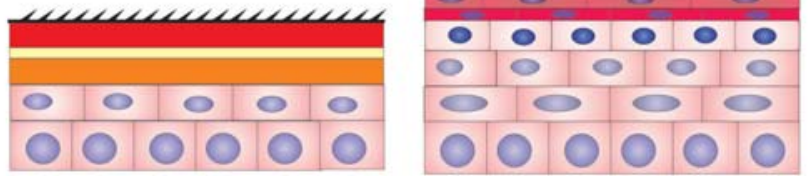

Cell proliferation (Stage 1c) Layer specification (Stage 2-4)

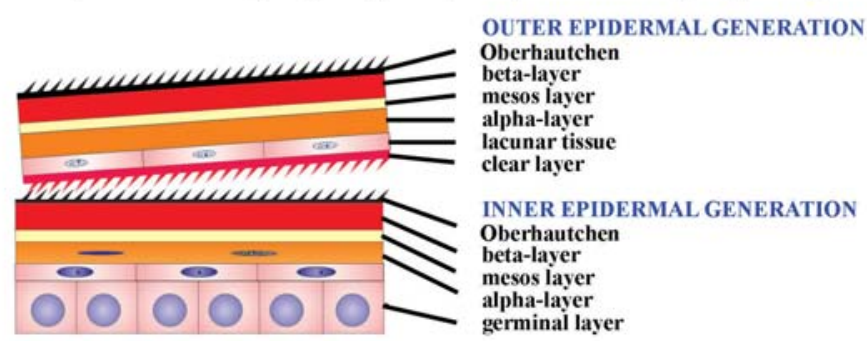

Terminal differentiation (Stage 5-6) tially). As cells become more differentiated, they are displaced more externally to serve as the first line of defense. Eventually, they are worn and sloughed off. This is seen in alligator scales and also in the inter-follicular epidermis of mammals. In snake and lizard, the strategy is episodic. This allows the formation of multiple different layers (basal layer $\rightarrow$ different supra-basal layers at different times) which offer different and more complete protection. The cost is that at a particular point, the old epidermis has to be shed, leaving the animals vulnerable. In snakes, this usually occurs simultaneously across the whole body, so the molted skin can be in one sheet. In lizard, this can occur in patches. Birds and mammals also use this episodic strategy to generate complex cell types in feathers and hairs in cycles. Since stem cells and actively proliferating cells reside in the follicle, which is open to the external surface only via a small orifice, this does not lead the problem of vulnerability during shedding. In the inter-follicular epidermis, the continuous replacement strategy is still used. Thus by combining continuous and episodic strategies and by positioning each appendage with proper spacing, the integument is well protected. Furthermore, different skin regions can display appendages with different characteristics, lengths and colors, depending on need. This is another example of how topological arrangement of stem cells, TA cells and differentiated cells can lead to spatial and functional diversity of ectodermal organs (Chuong et al., 2006).

\section{Conclusions}

To trace how new cellular and molecular events allowed evolutionary novelty, and led to the evolution of feathers and hairs, we have to study the prototypic pathway in reptilian scales. Studies on the genomic and protein evolution of corneous proteins involved in the establishment of epidermal barrier molecules, $\alpha-/ \beta$-keratins and their associated proteins among amniotes, will provide novel information on their evolutionary relationship-and molecular functions. Among amniotes, there are different strategies to for the management of homeostasis among stem, transient amplifying, and differentiated cells, and the reestablishment of homeostasis during regeneration. Hairs and feathers are successful examples, but it will be important to examine how gene regulatory networks were modified from the

Fig 8. Growth, proliferation, differentiation and shedding cycling in anole scales. (A) Schematic drawing showing the histological changes in the epidermis of squamates. The multi-layered epidermis can be divided into two phases of the sloughing cycle. The resting phase is represented by stage 1, which can be further divided into immediate post-shedding phase (1a), the perfect resting phase (1b) and the prerenewal phase (1c). The renewal phase consists of a series of stages with new layers being formed and specified. Depending on the layers present, they are divided into stage 2 through stage 6 . The outer generation (OG) consists of Obo (Oberhäutchen), $\beta o$ ( $\beta$-layer), mo (mesos layer), $\alpha o$ ( $\alpha$ layer), It (lacunar tissue) and cl (clear layer). The new inner generation (IG) comprises Obi (Oberhäutchen), $\beta i$ ( $\beta$-layer), mi (mesos layer), $\alpha i$ (a partially formed $\alpha$-layer). sg, germinal layer; sb, stratum basale. At the right side, the reverse triangle at the end of stage 6 marks the time of shedding. Panel $A$ is from Landmann, 1986. (B) Schematic drawing to show the three major cellular events. Cell proliferation occurs in stage 1c. Specification and initial differentiation of different epidermal layers takes place from stage 2 to stage 4. Terminal differentiation occurs in stages 5 and 6 . 
basal network for scales in a succession of evolutionary novel cellular events. We have identified the formation of localized growth zones and the invagination of follicles as a key step. The spatial arrangement of these localized growth units is not only important for integument function but also for understanding biological pattern formation. Since most scales are short in height, their arrangement, size and shapes are clearly revealed, making them an exquisite model for experimental analyses on how biological patterns form. While research on reptile scales has been carried out, the analyses of molecules involved in scale morphogenesis have lagged behind. Here we underscore how the development of this novel experimental model will be valuable in filling in the gaps of our understanding of the biology of amniote integuments.

\section{Acknowledgement}

This work is supported by grants from NIA and NIAMS (CMC). Dr. Alibardi is supported by a $60 \%$ University of Bologna Grant. Dr. Cheng Chang is supported by grants from China NSFC 30770240 and Lanzhou University. REB is supported by an RCUK Fellowship, a Microsoft European Research Fellowship and a Junior Research Fellowship from St Hugh's College, Oxford. PKM is partially supported by a Royal SocietyWolfson Merit Award.

\section{References}

ALEXANDER, N. J. (1970). Comparison of $\alpha$ an $\beta$ keratin in reptiles. $Z$. Zellforsch. 110: 153-165.

ALIBARDI, L. (1996) Scale morphogenesis during embryonic development in the lizard Anolis lineatopus. J. Anat. 188:713-725.

ALIBARDI, L. (1998). Differentiation of the epidermis during scale formation in embryos of lizard. J. Anat. 192: 173-186.

ALIBARDI, L. (1999). Keratohyalin-like granules and differentiation of the shedding complex in embryonic and regenerating epidermis of lizards and Sphenodon (Reptilia, Lepidosauria). Amphibia-Reptilia. 20: 11-23.

ALIBARDI, L. (2000). Ultrastructural localization of alpha-keratins in the regenerating epidermis of the lizard Podarcis muralis during formation of the shedding layer. Tissue Cell. 32: 153-162.

ALIBARDI, L. (2001). Keratohyalin-like granules in lizard epidermis: evidence from cytochemical, autoradiographic, and microanalytical studies. J. Morphol. 248: 64-79.

ALIBARDI, L. (2002a). Histidine uptake in the epidermis of lizards and snakes in relation to the formation of the shedding complex. J. Exp. Zool. 292: 331-344.

ALIBARDI, L. (2002b). Loricrine-like immunoreactivity during keratinization in lizard epidermis. J. Morphol. 254: 132-138.

ALIBARDI, L. (2003). Aaptation to the land: The skin of reptiles in comparison to that of amphibians and endotherm amniotes. J. Exp. Zoolog. B. Mol. Dev. Evol. 298(1): 12-41.

ALIBARDI, L. (2004a). Dermo-epidermal interactions in reptilian scales: speculations on the evolution of scales, feathers, and hairs. J. Exp. Zoolog. B. Mol. Dev. Evol. 302(4): 365-383.

ALIBARDI, L. (2004b). Fine structure and immunocytochemistry of monotreme hairs with emphasis on the inner root sheath and trichohyaline-based cornification during hair evolution. J. Morphol. 261: 345-363.

ALIBARDI, L. (2004c). Comparative aspects of the inner root sheath in adult and developing hairs of mammals in relation to the evolution of hairs. J. Anat. 205: 179-200.

ALIBARDI, L. (2006a). Structural and immunocytochemical characterization of keratinization in vertebrate epidermis and epidermal derivatives. Int. Rev. Cytol. 253: $177-259$.

ALIBARDI, L. (2006b). Cells of embryonic and regenerating germinal layers within barb ridges: implication for the development, evolution and diversification of feathers. J. Subm. Cytol. Pathol. 38: 51-76.
ALIBARDI, L., SAWYER, R. H. (2002). Immunocytochemical analysis of $\beta$-keratins in the epidermis of chelonians, lepidosaurians, and archosaurians. J. Exp. Zool. 293: 27-38.

ALIBARDI, L., THOMPSON, M. B. (2000). Scale morphogenesis and ultrastructure of dermis during embryo development in the alligator (Alligatormississippiensis, Crocodilia, Reptilia). Acta Zool-Stockolm. 81: 325-338.

ALIBARDI, L., THOMPSON, M. B. (2001). Fine structure of the developing epidermis in the embryo of the american alligator (Alligatormississippiensis, Crocodlilia, Reptilia). J. Anat. 198: 265-282.

ALIBARDI, L., THOMPSON, M. B. (2002). Keratinization and ultrastructure of the epidermis of late embryonic stages in the alligator (Alligator mississippiensis). J. Anat. 201: 71-84.

ALIBARDI, L., TONI, M. (2005). Immunolocalization and characterization of cornification proteins in snake epidermis. Anat. Rec. A. Discov. Mol. Cell Evol. Biol. 282: 138-146.

ALIBARDI, L., TONI, M. (2006). Cytochemical, biochemical and molecular aspects of the process of keratinization in the epidermis of reptilian scales. Prog. Histochem. Cytochem. 40: 173-134.

ALIBARDI, L., TONI, M., DALLLA, V. L. (2007). Review. Hard keratins in reptilian epidermis in comparison to those of birds and mammals. Exp. Dermatol. 16 961-976.

BADEN, H. P., MADERSON, P. F. A. (1970). Morphological and biophysical identification of fibrous proteins in the amniote epidermis. J. Exp. Zool. 174:225232.

BADEN, H. P., SVIOKLA. S., ROTH, I. (1974). The structural protein of reptilian scales. J. EXp. Zool. 187: 287-294.

BAKER, R. E., SCHNELL, S., PHILIP, PK, (2009). Waves and patterning in developmental biology: vertebrate segmentation and feather bud formation as case studies. Int. J. Dev. Biol. 53: 783-794. (doi: 10.1387/ijdb.072493rb)

BENTLEY, P. J., SCHMIDT-NIELSEN, K. (1966). Cutaneous water-loss in reptiles. Science. 151: 1547-1549.

BRUSH, A. H. (1993). The origin of feather: a novel approach. In: Farner, D., Kling, J., Parker, K. editors. Avian biology. New York: Academic Press. pp. 121-162.

CARVER, W. E., SAWYER, R. H. (1987). Development and keratinization of the epidermis in the common lizard, Anolis carolinensis. J. Exp. Zool. 243: 435-443.

CHANG, C., ZHENG, R. L. (2003). Effects of ultraviolet B on epidermal morphology, shedding, lipid peroxide, and antioxidant enzymes in Cope's rat snake (Elaphe taeniura). J. Photochem. Photobiol. B. Biol. 72: 79-85.

CHEN, P., DONG, Z., ZHEN, S. (1998). An exceptionally well preserved theropod dinosaur from the Yixian Formation of China. Nature. 391: 147-52.

CHODANKAR, R., CHANG, C.-H., YUE, Z., SUKSAWEANG, S., BURRUS, L., CHUONG, C.-M., AND WIDELITZ, R.B. 2003. Shift of Localized Growth Zones (LoGZ) Contributes to the Morphogenesis of Skin Appendages: Association with Wnt/B-catenin activities. J. Invest. Dermatol. 120: 19-26.

CHUONG, C.-M. (1998). Molecular Basis of Epithelial Appendage Morphogenesis. Landes Bioscience, Austin, TX: Landes Bioscience.

CHUONG, C.-M., CHODANKAR, R., WIDELITZ, R.B., JIANG, T. X. (2000). EvoDevo of Feathers and Scales: Building complex epithelial appendages. Curr. Opin. in Dev. and Gen. 10: 449-456.

CHUONG, C.-M., COTSARELIS, G., STENN, K. (2007). Defining hair follicles in the age of stem cell bio-engineering. J. Invest. Dermatol. 127: 2098-2100.

CHUONG, C.-M., HOMBERGER, D. G. (2003). Development and Evolution of the Amniote Integument: Current Landscape and Future Horizon. J. Exp. Zool. 298B: 1-11.

CHUONG, C.-M., HOU, L. H., CHEN, P. J., WU, P., PATEL, N., CHEN, Y. P. (2001) Dinosaur's feather and Chicken's tooth? Tissue engineering of the integument. Eur. J. Dermatol. 11: 286-292.

CHUONG C.-M., NICKLOFF, B.J., ELIAS P.M., GOLDSMITH, L.A., MACHER, E., MADERSON, P.A., SUNDBERG, J.P., TAGAMI, H., PLONGKA, P.M., THESTRUP-PEDERSEN, K., BERNARD, B.A., SCRODER, J.M., DOTTO, P., CHANG C,-H., WILLIAMS, M.L., FEINGOLD, K.R., KING, L.E., KLIGMAN, A.M., REES, J.L., CHRISTOPHERS, E. (2002). What is the 'true' function of skin. Exp. Dermatol. 11: 159-187.

CHUONG, C-M., WU, P., ZHANG, F.-C., XU, X., YU, M., WIDELITZ, R. B., JIANG, T. -X., HOU, L. (2003). Adaptation to the Sky: Defining the Feather with 
Integument fossils from Mesozoic China and experimental evidence from molecular laboratories. J. Exp. Zool. 298B: 42-56.

CHUONG, C-M., WU, P., PLIKUS MV, JIANG, TX, WIDELITZ, RB. (2006). Engineering Stem cells into organs: Topobiological transformations demonstrated by beak, feather and other ectodermal organ morphogenesis. Curr. Top. Dev. Biol. 72: 237-274.

COOPER, W. E., GREENBERG, N. (1992). Reptilian coloration and behaviour. In C Gans, F Billett, MADERSON, P. F. A., eds. Biology of the reptilia. Vol. 18. Physiology E. Chicago-London: Chicago University Press, pp. 298-423.

COTSARELIS G. (2006). Epithelial stem cells: a folliculocentric view. J Invest Dermatol. 126: 1459-1468.

DALLA VALLE, L., NARDI, A., TOFFOLO, V., NIERO, C., TONI, M., ALIBARDI, L. (2007). Cloning and characterization of scale $\beta$-keratins in the differentiating epidermis of geckoes show they are glycine-proline-serine-rich proteins with a central motif homologous to avian beta-keratins. Dev. Dyn. 236: 374-388.

DALLA VALLE, L., TOFFOLO, V., BELVEDERE, P., ALIBARDI, L. (2005). Isolation of a mRNA encoding a glycine-proline-rich beta-keratin expressed in the regenerating epidermis of lizard. Dev. Dyn. 234: 934-947.

DAVIS, J. E., SPOTILA, J. R., SCHEFLER, W. C. (1980). Evaporative water loss from the american alligator, Alligator mississippiensis: the relative importance of respiratory and cutaneous components and the regulatory role of the skin. Comp. Biochem. Phys. 67A: 439-446.

DHOUAILLY, D. (1975). Formation of cutaceous appendages in dermo-epidermal recombinaitons between reptiles, birds and mammals. Wilhelm Roux' Arch. Entwicklungsmech Org. 177: 323-40.

DHOUAILLY, D., HARDY, M. H., SENGEL, P. (1980). Formation of feathers on chick foot scales: a stage-dependent morphogenetic response to retinoic acid. J. Embryol. Exp. Morphol. 58: 63-78.

DHOUAILLY, D., SUN, T. T. (1989). The mammalian tongue filiform papillae: a theoretical model for primitive hairs. In Trends in human hair growth and Alopecia research Eds. D. van Neste, LaCapelle, J. M., Antoine, J. L. Kluwer Acad. Pub. Boston, pp. 29-34.

DUNSON, W. A., MAZZOTTI, F. J. (1988). Some aspects of water and sodium exchange of freshwater crocodilians in fresh water and sea water: role of the integument. Comp. Biochem. Phys. 90A: 391-396.

FLAXMAN, B. A. (1972). Cell differentiation and its control in the vertebrate epidermis. Am. Zool. 12: 13-25.

FLAXMAN, B. A., MADERSON, P. F. A. (1973). Relationship between pattern of cell migration from the germinal layer and changing patterns of differentiation in the lizard epidermis. J. Exp. Zool. 183, 209-216.

FRASER, R. D., PARRY, D. A. (1996). The molecular structure of reptilian keratin. Int. J. Biol. Macromol. 19: 207-211.

FUCHS, E., MARCHUK, D. (1983). Type I and type II keratins have evolved from lower eukaryotes to form the epidermal intermediate filaments in mammalian skin. Proc. Natl. Acad. Sci. USA. 80: 5857-5861.

GREGG, K., ROGERS, G. (1986). Feather keratins: composition, structure and biogenesis. In: Bereither-Hahn J, Matoltsy G, Sylvia- Richards K, editors. Biology of the integument: vertebrates. New York: Springer-Verlag. pp. 666694.

HARRIS, M. P., FALLON, J. F., PRUM, R. O. (2002). Shh-Bmp2 signaling module and the evolutionary origin and diversification of feathers. J. Exp. Zool.294(2):160176.

JONES, T. D., RUBEN, J. A., MARTIN, L. D., KUROCHKIN, E. N., FEDUCCIA, A., MADERSON, P. F., HILLENIUS, W. J., GEIST, N. R., ALIFANOV, V. (2000). Nonavian feathers in a late Triassic archosaur. Science. 288: 2202-2205.

JUNG, H.-S., FRANCIS-WEST, F., WIDELITZ, R.B, JIANG, T.-X., TING, S., TICKLE, C., WOLPERT, L. AND CHUONG, C.-M., (1998). Local inhibitory action of BMPs and their relationships with activators in feather formation: Implications for periodic patterning. Dev Bio/196: 11-23.

KELLER, E. F., SEGEL, L. A., (1970). Initiation of slime mold aggregation viewed as an instability. J. Theor. Biol. 26: 399-415.

KONDO, S., ASAI, R. (1995). A reaction-diffusion wave on the skin of the marine angelfish Pomacanthus. Nature. 376: 765-768.

KONDO, S, IWASHITA, M. AND YAMAGUCHI, M. (2009). How animals get their skin patterns: fish pigment pattern as a live Turing wave. Int. J. Dev. Biol. 53:
851-856. (doi: 10.1387/ijdb.072502sk).

LANDMANN, L. (1979). Keratin formation and barrier mechanisms in the epidermis of Natrix natrix (Reptilia: Serpentes): an ultrastructural study. J. Morphol. 162: 93-126.

LANDMANN, L. (1986). The skin of Reptiles: epidermis and dermis. In: BereitherHahn J, Matoltsy G, Sylvia-Richards K, editors. Biology of the integument: vertebrate. New York: Springer Verlag. pp. 150-187.

LANDMANN, L., STOLINSKI, C., MARTIN, B. (1981). The permeability barrier in the epidermis of the grass snake during the resting stage of the sloughing cycle. Cell Tissue Res. 215: 369-382.

LILLYWHITE, H. B. (2006). Water relations of tetrapod integument. J. Exp. Biol. 209: 202-226.

LILLYWHITE, H. B., MADERSON, P. F. A. (1982). Skin structure and permeability. In Gans, C., Pough, F. H. eds. Biology of the Reptilia; Physiological Ecology. Vol. 12. New York, London: Academic Press, pp. 397-442.

LIN, C.-M., JIANG, T. X., WIDELITZ, R. B., CHUONG, C.-M. (2006). Molecular signaling in feather morphogenesis. Curr. Opin. Cell Biol. 18: 730-741.

LUCAS, A. M., STTETENHEIM, P. R. (1972). Avian Anatomy Integument. In: Agriculture Handbook 362. Agricultural Research Services. Washington, DC: US Department of Agriculture.

MADERSON, P. F. A. (1965). Histological changes in the epidermis of snakes during the sloughing cycle. J. Zool. (London) 146: 98-113.

MADERSON, P. F. A. (1966). Histological changes in the epidermis of the Tokay (Gekko gecko) during the sloughing cycle. J. Morphol. 119: 39-50.

MADERSON, P. F. A. (1968). Observations on the epidermis of the Tuatara (Sphenodon punctatus). J. Anat. 103: 311-320.

MADERSON, P. F. A. (1970). Lizard hands and lizard glands: Models for evolutionary study. Forma. Et. Functio. 3: 179-204.

MADERSON, P. F. A. (1972). When? Why? and How? Some speculations on the evolution of the vertebrate integument. Am. Zool. 12: 159-171.

MADERSON, P. F. A. (1985). Some developmental problems of the reptilian integument. In: Gans C, Billett F, Maderson PF, editors. Biology of reptilia. New York: John Wiley \& Sons. pp. 525-598.

MADERSON, P.F.A. (2003). Mammalian skin evolution: a reevaluation. Exp. Dermatol. 12: 233-236.

MADERSON, P. F. A., ALIBARDI, L. (2000). The development of the sauropsid integument: a contribution to the problem of the origin and evolution of feathers. Am. Zool. 40: 513-529.

MADERSON, P. F. A., LICHT, P. (1967). The epidermal morphology and sloughing frequency in normal and prolactin injected Anolis carolizensis (Iguanidae, Lacertilia). J. Morphol. 123: 157-172.

MADERSON, P. F. A. (1985). Some developmental problems of the reptilian integument; MADERSON, P. F. A., GANS, C., BILLETT, F. eds. Biology of the Reptilia. Vol. 14. New York: John Wiley \& Sons; pp. 525-598.

MADERSON, P. F. A., RABINOWITZ, T., TANDLER, B., ALIBARDI, L. (1998). Ultrastructural contributions to an understanding of the cellular mechanisms involved in lizard skin shedding with comments on the function and evolution of a unique Lepidosaurian phenomenon. J. Morphol. 236: 1-24.

MAINI, P. K., MYERSCOUGH, M. R., MURRAY, J. D., WINTERS, K. H. (1991). Bifurcating spatially heterogeneous solutions in a chemotaxis model for biological pattern formation. Bull. Math. Biol. 53: 701-719.

MAINI, PK, BAKER, RE, CHUONG, CM., (2006). The Turing model comes of molecular age. Science. 314: 1397-1398.

MENON, G. K., BROWN, B. E., ELIAS, P. M. (1986). Avian epidermal differentiation: role of lipids in permeability barrier function. Tissue Cell. 18: 71-82.

MENON, G. K., MADERSON, P. F. A., DREWES, R. C., BAPTISTA, L. F., PRICE, L. F., ELIAS, P. M. (1996). Ultrastructural organization of avian stratum corneum lipids as the basis for facultative cutaneous waterproofing. J. Morphol. 227: 113.

MURRAY, J. D. (1988). How the leopard gets its spots. Sci. Amer. 258: 80-87.

MURRAY, J. D., MYERSCOUGH, M. R. (1991). Pigmentation pattern formation on snakes. J. Theor. Biol. 149: 361-375.

NAGORCKA, B. N., (1983-1984). Evidence for a reaction-diffusion system as a mechanism controlling mammalian hair growth. Biosystems. 16: 323-332. 
NAGORCKA, B. N., MOONEY, J. R. (1982). The role of a reaction-diffusion system in the formation of hair fibres. J. Theor. Biol. 98: 575-607.

OSTER, G., MURRAY, J. D., HARRIS, A. K. (1983). Mechanical aspects of mesenchymal morphogenesis. J. Embryol. Exp. Morphol. 78: 83-125.

PAINTER, K. J., MAINI, P. K., OTHMER, H. G. (1999). Stripe formation in juvenile Pomacanthus explained by a generalized Turing mechanism with chemotaxis. Proc. Natl. Acad. Sci USA. 96: 5549-5554.

PATLAK, C. A. (1963). Random walk with persistence and external bias. Bull. Math. Biophys. 15: 311-338.

PIANKA, E. R., VITT, L. J. (2003). Lizards: Windows to the Evolution of Diversity. University of California Press; 1st ed. pp. 1-346

PLIKUS, M. V., SUNDBERG, J. P., CHUONG, C. -M. (2007). Mouse Skin Ectodermal Organs. In The Mouse in Biomedical Research, Academic Press. NY. pp. 691-730.

PLIKUS M.V. and CHUONG C.M. (2008). Complex hair cycle domain patterns and regenerative hair waves in living rodents. J. Invest Dermatol. 128: 1071-1080.

PLIKUS M. V., MAYER J. A., DE LA CRUZ D., BAKER R. E., MAINI P. K., MAXSON R. AND CHUONG C.M. (2008). Cyclic dermal BMP signaling regulates stem cell activation during hair regeneration. Nature. 451: 340-344.

PLIKUS, M.V. WIODELITZ, R.B., MAXSON R. and CHUONG, C.M. (2009). Analyses of regenerative wave patterns in adult hair follicle populations reveal macro-environmental regulation of stem cell activity. Int. J. Dev. Biol. 53: 857868. doi: (10.1387/ijdb.072564mp)

PRESLAND, R. B., GREGG, K., MOLLOY, P. L., MORRIS, C. P., CROCKER, L. A., ROGERS, G. E. (1989a). Avian keratin genes. I. A molecular analysis of the structure and expression of a group of feather keratin genes. J. Mol. Biol. 209: 549-59.

PRESLAND, R. B., WHITBREAD, L. A., ROGERS, G. E. (1989b). Avian keratin genes. II. Chromosomal arrangement and close linkage of three gene families. J. Mol. Biol. 209: 561-76.

PRUM, R. O. (1999). Development and evolutionary origin of feathers. J. Exp. Zool. 285: 291-306.

PRUM, R. O. (2005). Evolution of the morphological innovations of feathers. J. Exp. Zoolog. B. Mol. Dev. Evol. 304(6):570-9.

PRUM, R. O., BRUSH, A. H. (2002). The evolutionary origin and diversification of feathers. Q. Rev. Biol. 77: 261-95.

REGAL, P. J. (1975). The evolutionary origin of feathers. Q. Rev. Biol. 50: 35-66.

ROGERS, G. (2004). Hair follicle differentiation and regulation. Int. J. Dev. Biol. 48: 163-170.

RINGVOLD, A., ANDERSSEN, E., JELLUM, E., BJERKÅS, E., SONERUD, G. A., HAALAND, P. J., DEVOR, T. P., KJØNNIKSEN, I. (2003). UV-Absorbing Compounds in the Aqueous Humor from Aquatic Mammals and Various NonMammalian Vertebrates. Ophthalmic Res. 35: 208-216

SAWYER, R. H., GLENN, T. C., FRENCH, J. O., MAYS, B., SHAMES, R. B., BARNES, G. L., RHODES, W., ISHIKAWA, Y. (2000). The expression of betakeratins in the epidermal appendages of reptiles and birds. Am. Zool. 40: 530539.

SAWYER, R. H., KNAPP, L. W. (2003). Avian skin development and the evolutionary origin of feathers. J. Exp. Zool. Part. B Mol. Dev. Evol. 298: 57-72.

SAWYER R. H., ROGERS L., WASHINGTON L., GLENN T.C., KNAPP L.W. (2005). Evolutionary origin of the feather epidermis. Dev Dyn 232: 256-67.

SCHNAKENBERG, J. (1979). Simple chemical reaction systems with limit cycle behaviour. J. Theor. Biol. 81, 389-400.

SHAMES, R. B., KNAPP, L. W., CARVER, W. E., WASHINGTON, L. D., SAWYER, R. H. (1989). Keratinization of the outer surface of the avian scuatate scale: interrelationship of alpha and beta keratin filaments in a cornifying tissue. Ce/l Tissue Res. 257: 85-92.

SHAW, L. J., MURRAY, J. D. (1990). Analysis of a model for complex skin patterns.
SIAM J. Appl. Math. 50: 628-648.

SICK, S. et al. (2006). WNT and DKK determine hair follicle spacing through a reaction-diffusion mechanism. Science. 314: 1447-1450.

SPEARMAN, R.I.C. (1964). The evolution of mammalian keratinized structures. In: Ebling, F. J. editor. The mammalian epidermis and its derivatives. London: Zoological Society. pp. 67-81.

STEINERT, P. M., FREEDBERG, I. M. (1991). Molecular and cellular biology of keratins. In: Goldsmith LA, editor. Physiology, biochemistry, and molecular biology of the skin. New York: Oxford University Press. pp. 113-147.

TANAKA, S., KATO, Y. (1983). Epigenesis in developing avian scales. II. Cell proliferation in relation to morphogenesis and differentiation in the epidermis. $J$. Exp. Zool. 225: 271-83.

TONI, M., ALIBARDI, L. (2007). Alpha- and beta-keratins of the snake epidermis. Zoology. 110: 41-47

TONI, M., VALLE, L. D., ALIBARDI, L. (2007). Hard (Beta-)keratins in the epidermis of reptiles: composition, sequence, and molecular organization. J. Proteome. Res. 6:3377-92.

TURING, A. M. (1952). The chemical basis of morphogenesis. Roy. Soc. Lond. Phil. Trans. B. 237: 37-72.

VON DURING, M., MILLER, M. L. (1979). Sensory nerve endings of the skin and deeper structures. In: GANS, C. eds. Biology of the Reptilia, Neurology $A$ Academic Press, London, New York and San Francisco. 9: 407-441.

WAGNER, G. P. (2007). The developmental genetics of homology. Nat. Rev. Genet. 8:473-9.

WHITBREAD, L. A., GREGG, K., ROGERS, G. E. (1991). The structure and expression of a gene encoding chick claw keratin. Gene. 101: 223-229.

WIDELITZ, R. B., JIANG, T. -X., LU, J. -F., CHUONG, C. -M. (2000). Beta catenin in epithelial morphogenesis: Conversion of part of avian foot scales into feather buds with a mutated beta catenin. Dev. Biol. 219: 98-114.

WIDELITZ, R. B., JIANG, T. -X., YU, M., WU, P., YUE, Z., CHUONG, C. -M. (2003). Molecular biology of feather morphogenesis: A testable model of Evo-Devo research. J. Exp. Zool. 298B: 109-222.

WU, P., HOU, L., PLIKUS, M., HUGHES, M., SCEHNET, J., SUKSAWEANG, S., WIDELTZ, R. W., CHUONG, C. -M. (2004). Evo-Devo of amniote integuments and appendages. Int. J. Dev. Biol. 48: 249-270.

WYLD, J. A., BRUSH, A. H. (1979). The molecular heterogeneity and diversity of reptilian keratins. J. Mol. Evol. 12: 331-347.

WYLD, J. A., BRUSH, A. H. (1983). Keratin diversity in the reptilian epidermis. J. EXp. ZOOl. 225: 387-396.

XU, X., WANG, X. L., WU, X. C. (1999b). A dromaeosaurid dinosaur with a filamentous integument from the Yixian Formation of China. Nature. 401: 262266.

XU, X., ZHOU, Z., PRUM, R. O. (2001). Branched integumental structures in Sinornithosaurus and the origin of feathers. Nature. 410: 200-204.

XU, X., ZHOU, Z., WANG, X., KUANG, X., ZHANG, F., DU, X. (2003). Four-winged dinosaurs from China. Nature. 421: 335-340.

YU, M., WU, P., WIDLITZ, R. B., CHUONG, C. -M. (2002). The Morphogenesis of feathers. Nature 420: 308-312.

YU, M., YUE, Z., WU, P., WU, D.-Y., MAYER, J. A., MEDINA, M., WIDELITZ, R. B. JIANG, T. -X., CHUONG, C. -M. (2004). The developmental biology of feather follicles. Int. J. Dev. Biol. 48:181-191.

YUE, Z., JIANG, T. -X., WIDELITZ. R. B., AND CHUONG, C. -M. (2005). Mapping stem cell activities in the feather follicle. Nature 438: 1026-1029.

YUE, Z., JIANG, T. X., WIDELITZ, R. B., CHUONG, C. -M. (2006) Wnt3a gradient converts radial to bilateral feather symmetry via topological arrangement of epithelia. Proc. Natl. Acad. Sci USA. 103: 951-955.

ZHOU, Z., BARRETT, P.M., HILTON, J. (2003). An exceptionally preserved Lower Cretaceous ecosystem. Nature 421: 807-14. 


\section{Further Related Reading, published previously in the Int. J. Dev. Biol.}

See our Special Issue Skin Development edited by Danielle Dhouailly at:

http://www.ijdb.ehu.es/web/contents.php?vol=48\&issue=2-3

\section{Evo-Devo of amniote integuments and appendages}

Ping Wu, Lianhai Hou, Maksim Plikus, Michael Hughes, Jeffrey Scehnet,

Sanong Suksaweang, Randall Widelitz, Ting-Xin Jiang and Cheng-Ming Chuong

Int. J. Dev. Biol. (2004) 48: 249-270

Scale development in fish: a review, with description of sonic hedgehog (shh) expression in the zebrafish (Danio rerio)

Jean-Yves Sire and Marie-Andrée Akimenko

Int. J. Dev. Biol. (2004) 48: 233-247

5 yr ISI Impact Factor $(2008)=3.271$

The biology of feather follicles

Mingke Yu, Zhicao Yue, Ping Wu, Da-Yu Wu, Julie-Ann Mayer, Marcus Medina, Randall B Widelitz, Ting-Xin Jiang and Cheng-Ming Chuong

Int. J. Dev. Biol. (2004) 48: 181-191

The different steps of skin formation in vertebrates

Isabel Olivera-Martinez, Jean P Viallet, Frederic Michon, David J Pearton and Danielle Dhouailly

Int. J. Dev. Biol. (2004) 48: 107-115

Skin field formation: morphogenetic events

Danielle Dhouailly, Isabel Olivera-Martinez, Ingrid Fliniaux, Sylvain Missier, Jean P Viallet and Jacques Thélu

Int. J. Dev. Biol. (2004) 48: 85-91

Expression and distribution of regeneration-responsive molecule during normal development of the newt, Cynops pyrrhogaster

Y Imokawa and G Eguchi

Int. J. Dev. Biol. (1992) 36: 407-412

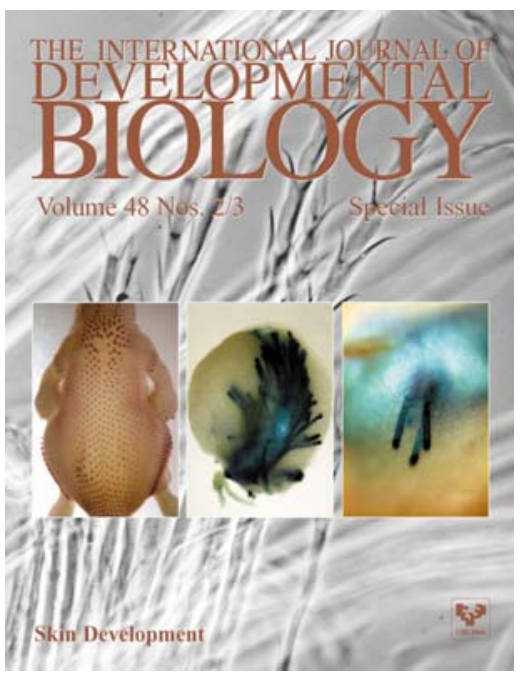

For all the latest on Pattern Formation research, see our latest Special Issue edited by C.-M. Chuong and M.K. Richardson.

http://www.ijdb.ehu.es/web/contents.php?vol=53\&issue=5-6

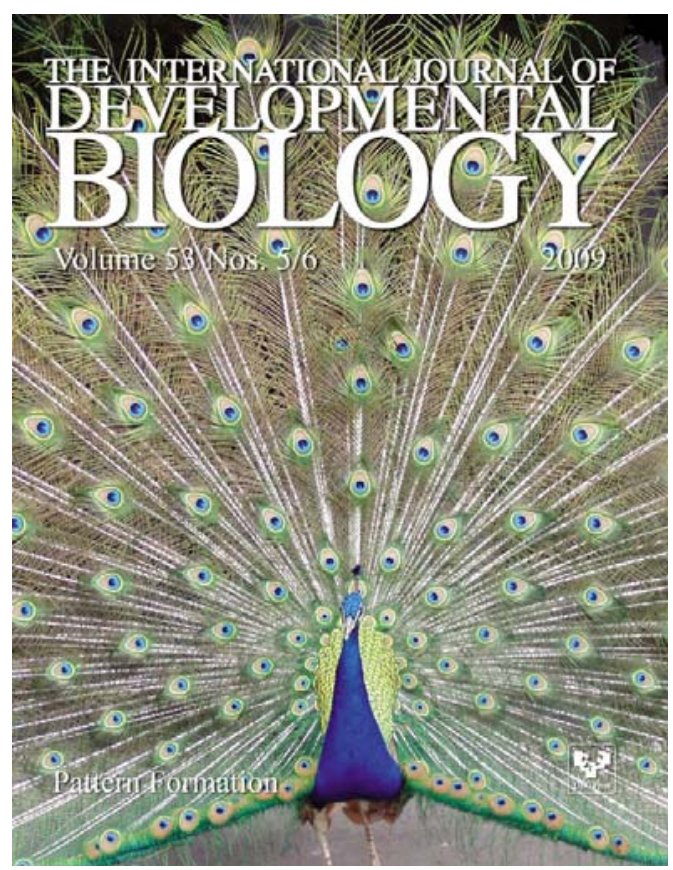

